\title{
Captivating thoughts: nocturnal pollution, imagination and the sleeping mind in the twelfth and thirteenth centuries
}

William F. MacLehose

Science and Technology Studies, University College London, London, United Kingdom

NOTE: This is the prepublication version of an article which will appear in the Journal of Medieval History 46 (2020): 1-35. Please cite the published version.

Received: 25 June 2018

Accepted: 30 October 2018

Medieval attempts to understand nocturnal emissions - involuntary bodily excretions during sleep which were identified as morally ambiguous - became extensive explorations of the unique and problematic features of sleep and the mental state it produced. During the twelfth and thirteenth centuries, nocturnal pollutions became the object of an intensive scrutiny of sleep as a site of moral concern. Causal explanations often centred on human psychology, in particular the unusual status of the sleeping mind, in an attempt to understand the intricate ways in which mind, body and soul were uniquely bound together in sleep. The mental states before, during and after sleep were understood to interact with one another in complex ways which centred on questions of culpability and its lack. A comparison of medical, natural philosophical, theological and canon law materials discussing nocturnal pollution reveals a preoccupation with the sleeper's mind as exceptional, uncontrollable and problematic.

Keywords: history of psychology; medieval medicine; natural philosophy; theology; theories of mind and body; history of sleep 
Night-time was a source of great concern in medieval society. With its shadowy cast of thieves, murderers, adulterers, revellers, pagans and devils, the period between dusk and sunrise was believed to bring with it many dangers, both physical and spiritual. Sleep, the activity most closely associated with night-time, compounded the problems of the dark, adding to the various external threats a set of internal concerns that presented unique challenges to medieval thinkers. Particularly during the twelfth and thirteenth centuries, writers turned their attention to sleep and the anomalous behaviours associated with it, including night terrors, sleepwalking, insomnia and erotic dreams. It is the last of these conditions of sleep and particularly its physical manifestation, nocturnal emission, which provides the focus for this study.

The historiography of nocturnal pollution, as the phenomenon was most commonly known in the Middle Ages, goes back only as far as an article by Michel Foucault from 1982, 'The Battle for Chastity,' originally intended for inclusion in volume three of his History of Sexuality. Foucault identified nocturnal emissions as a site of early Christian anxiety over male sexuality, particularly the inability of men to control their bodies. Since the 1990s, the few studies which have addressed medieval understandings of nocturnal pollutions have, understandably, followed Foucault's lead and focused on the history of sexuality, gender and religious views of ritual impurity. For scholars such as Dyan Elliott, Jacqueline Murray and Conrad Leyser, nocturnal pollution directly addressed medieval concerns over the disordered male body, and particularly highlighted the dangers posed to the spiritual purity and integrity of the cleric's soul. ${ }^{1}$

E-mail: w.maclehose@ucl.ac.uk Postal address: Science and Technology Studies, University College London, Gower Street, London WC1E 6BT, United Kingdom

${ }^{1}$ The following abbreviations are used in this paper: Aquinas, ST: Thomas Aquinas, S. Thomae Aquinatis Summa theologiae. 3 vols. (Taurini: Marietti, 1948-50) - references are to parts of the Summa; Aquinas, Super Sent.: Thomas Aquinas, Scriptum super libros Sententiarum Magistri Petri Lombardi episcopi Parisiensis, eds. 
This study seeks to shift the focus away from the body and toward medieval understandings of sleep and the resting mind as another fruitful way of understanding what nocturnal emissions signified to writers of the twelfth and thirteenth centuries. All of the central questions surrounding nocturnal emissions - questions of free will, culpability, fantasy versus reality, voluntary versus involuntary actions and thoughts, the relation between mind and body - were made more complicated due to the recognition that the polluter was asleep. By looking at a broad selection of sources encompassing medical, natural philosophical, theological and canon law materials, this essay suggests that nocturnal pollution became an object of considerable discussion which utilised the unique and problematic state of sleep to explore the boundaries of the body, mind and soul. The power of the mind to influence both body and soul appears as a recurring theme in the various literatures under discussion here. My interest lies primarily in the role of one part of the mind - the imagination - in creating a link between the waking and sleeping states and in problematising the relation between the sleeper's thoughts and actions.

Discussions of nocturnal pollutions appeared regularly in a variety of sources, many of which have been overlooked in the previous studies, which focused predominantly on theological and confessional literatures. This study seeks to identify commonalities, despite

R.P. Mandonnet and M.F. Moos. 4 vols. (Paris: P. Lethielleux, 1929-47); Bede, EH: Bède le Vénérable, Histoire ecclésiastique du peuple anglais, ed. Michael Lapidge. Sources chrétiennes 489-91 (Paris: Cerf, 2005); CCCM: Corpus Christianorum continuatio mediaevalis; CCSL: Corpus Christianorum series Latina; CSEL: Corpus scriptorum ecclesiasticorum Latinorum; Gratian, Decretum: Decretum Magistri Gratiani, in Corpus iuris canonici, ed. Emil Friedberg. 2 vols. (Leipzig: Tauchnitz, 1879-81), vol. 1; PL: Patrologiae cursus completus series Latina.

Michel Foucault, 'Le combat de la chasteté', Communications 35 (1982): 15-25, translated as 'The Battle for Chastity', in Western Sexuality: Practice and Precept in Past and Present Times, eds. Philippe Ariès and André Béjin (Oxford: Blackwell, 1985); Dyan Elliott, 'Pollution, Illusion and Masculine Disarray: Nocturnal Emissions and the Sexuality of the Clergy', in Constructing Medieval Sexuality, eds. Karma Lochrie, Peggy McCracken and James Schultz (Minneapolis: University of Minneapolis Press, 1997), 1-23, reprinted Dyan Elliott, Fallen Bodies: Pollution, Sexuality and Demonology in the Middle Ages (Philadelphia: University of Pennsylvania Press, 1999), chapter 1; Jacqueline Murray, 'Men's Bodies, Men's Minds: Seminal Emissions and Sexual Anxiety in the Middle Ages', Annual Review of Sex Research 8 (1997): 1-26; Conrad Leyser, 'Masculinity in Flux: Nocturnal Emission and the Limits of Celibacy in the Early Middle Ages', in Masculinity in Medieval Europe, ed. D.M. Hadley (London: Longman, 1998), 103-20. 
differences of emphasis and detail, between four literatures - theology, canon law, natural philosophy and medicine - in their understandings of nocturnal pollutions as in large part a product of the unique functioning of the mind in sleep. It argues that medieval authors often understood nocturnal pollution as the result of mental processes: the interplay between earlier sensory experiences in the waking state and the sleeper's imaginings. That is, much of the discussion of nocturnal emissions in the twelfth and thirteenth centuries highlighted the moral consequences of a physical act arising out of a mental preoccupation of the waking state, which was played out during sleep. But it was not only the relation between prior waking thoughts and the sleeping mind which was problematised here; by the thirteenth century, there is evidence of grave concerns over the other end of sleep, when the individual awoke and recalled the erotic dream encounter. The complex relation between sleep and the waking states on either side of it revolved around the individual's mental status, which determined his or her moral status.

This study argues that medieval attempts to understand nocturnal pollutions, as involuntary bodily excretions during sleep which were identified as morally ambiguous, became extensive explorations of the unique and problematic features of sleep and the mental state it produced. Over the course of the twelfth and thirteenth centuries, nocturnal pollutions became the object of an intensive scrutiny of sleep as a site of moral concern. Causal explanations often centred on human psychology, in particular the unusual status of the sleeping mind, in an attempt to understand the intricate ways in which mind, body and soul were uniquely bound together in sleep. The mental states before, during and after sleep were understood to interact with one another in complex ways which centred on questions of culpability and its lack. The literatures discussing nocturnal pollution reveal a preoccupation with the sleeper's mind as exceptional and problematic, uncontrollable and reflecting previous waking thoughts and desires. 


\section{Backgrounds and sources}

Nocturnal emissions appeared in the early Christian tradition as part of a tendency that problematised various types of bodily functioning. In many ways, Christian writers continued and expanded upon the laws regarding bodily impurity as laid down in the Pentateuch. Mosaic Law included an explicit reference to seminal emission in sleep (Deuteronomy 23:10-11) as a form of uncleanness which necessitated the removal of the nocturnal polluter from the camp. At sunset, after having physically cleansed himself, the polluter returned to a state of ritual purity which allowed him to be readmitted to the community. The passage appears not among discussions of sexuality but alongside a passage on excrement and its separation from the camp, all part of a concern over problematic bodily excretions. ${ }^{2}$

Early Christian writers often emphasised the sexual implications of a seminal emission in sleep, as seen in the writings of John Cassian and Augustine of Hippo in the early fifth century. For Cassian as for many other early Christian ascetics, a nocturnal pollution signified the weakness of the individual's will to resist temptation, even in dreams. The problem with nocturnal pollutions for these figures lay in human desire and the power of lower, bodily urges. Cassian recognised the dangers of the sleeping state: even the purest ascetic could endure 'phantasms of women' in his sleep and emit seed, thereby calling his spiritual status into question. As a result, Cassian attempted to create a path whereby the soul (and mind) could be purified of lustful desires; for Cassian, the cessation of nocturnal pollutions became the final stage of bodily ascesis and spiritual purity. Augustine, in contrast,

\footnotetext{
${ }^{2}$ Leviticus 15:16 refers to seminal emission without reference to sleep or night-time, so is generally interpreted much more broadly than the passage from Deuteronomy.
} 
was relatively lenient when it came to nocturnal pollutions, and acknowledged that they were often sexual in nature, but were ultimately not something one could necessarily control. ${ }^{3}$ Beyond the eremitical tradition with its search for individual corporeal and spiritual perfection, there developed a tradition concerning nocturnal pollution which focused, in a way parallel to the passage from Deuteronomy, on the individual's ritual purity and worthiness to participate in the religious life of the Christian community. Central to this view was whether or not the nocturnal polluter should have access to the Eucharist or, if he were a priest, whether or not he should officiate at the Mass. A letter purportedly written $c$.AD 600 by Pope Gregory the Great to Augustine, first archbishop of Canterbury, addressed exactly this issue and became the locus classicus for later discussions of nocturnal emissions and their implications, particularly during the twelfth and thirteenth centuries. The letter is now considered apocryphal, although in the early eighth century it was already accepted as legitimate by Bede in his Ecclesiastical History and became the authoritative text on the subject, as we shall see. ${ }^{4}$ Pseudo-Gregory's letter identified three types of nocturnal pollutions based on causes: some were brought on simply by a natural superfluity of bodily humours, others by an excess of food or drink and still others by a desire for a woman while awake. The letter is a rich text which weaves together causal explanations, ritual consequences and an awareness of the cognitive processes which could induce a nocturnal emission.

The three categories of nocturnal emission defined in Pseudo-Gregory's letter became the primary taxonomic division of the central Middle Ages, one which distinguished between

\footnotetext{
${ }^{3}$ John Cassian, Iohannes Cassiani Conlationes XXIIII, ed. Michael Petschenig. CSEL 14, part 2 (Vienna: apud C. Giroldi Filium, 1886), Spiritual Exercise 9; Augustine, De Genesi ad litteram, eds. P. Agaesse and A. Solignac. Oeuvres de Saint Augustin 49 (Paris: Institut d'études augustiniennes, 1970), 378-80 (12.15 [31]). For discussions of Cassian, see David Brakke, 'The Problematization of Nocturnal Emissions in Early Christian Syria, Egypt and Gaul', Journal of Early Christian Studies 3, no. 4 (1995): 419-60.

${ }^{4}$ See Bede, $E H, 1.27$, vol. 1, pp. 234-40; on the letter and the question of its authenticity, Leyser, 'Masculinity', $115-18$.
} 
interior and exterior, as well as somatic and cognitive. They encompassed the purely corporeal and internal (a natural humoral excess), the corporeal and external (a humoral excess induced by a culinary excess), and the mental and internal responding to an external stimulus (lustful thoughts). We shall focus on the last category in this tripartite model, although the other two will occasionally appear, when mental processes affect either of these two corporeal causes. Although what follows will concentrate on the cognitive aspects of the phenomenon, I by no means wish to suggest that the sources ignore or particularly downplay the corporeal aspects of nocturnal pollution. There is a wealth of information on the body's role in producing nocturnal emissions, but it moves in very different though equally intriguing directions from the primary concern of this study: the role of the mind in sleep. ${ }^{5}$ While discussions of nocturnal pollution appear occasionally in the early Middle Ages, we find in the central Middle Ages an immense amount of material on the subject from an impressive variety of sources. The phenomenon attracted considerable attention largely in an attempt to explain how and why (and, in the more religious materials, with what consequences) it occurred. Natural philosophers, including the compilers of the Prose Salernitan Questions and Albertus Magnus, sought to understand how the sleeper could produce and expel semen, and from around 1200 onward increasingly they turned to explanations from an explicitly Aristotelian perspective. Medical writers placed these natural explanations in the context of understanding and providing potential cures for the condition, as seen in the writings of Constantinus Africanus, Hildegard of Bingen and Bernard of Gordon. In contrast to the brief discussions of the subject in early medieval penitentials, books for confessors of the thirteenth century devoted a considerable amount of space to the topic, with an increasing focus on the mental conditions and processes which produced

\footnotetext{
${ }^{5} \mathrm{I}$ am in the midst of a separate study of the material on the corporeal aspects of nocturnal pollution, with a focus on causality and natural philosophical ideas of the bodily economy in theological and canon law sources.
} 
nocturnal emissions. Even more extensively, canon lawyers invoked and investigated PseudoGregory's letter, which Gratian incorporated wholesale into the Decretum (distinctio 6, chapters 1-3) alongside snippets from Isidore of Seville's Sentences. ${ }^{6}$ As a result, from the later twelfth century, discussions of nocturnal emissions appeared regularly in canon law writings, as the increasing number of commentaries and Summas glossed the passage. Theological materials tended to continue the biblical focus on ritual purity and the polluter's access to the Eucharist. Albert the Great and his student Thomas Aquinas introduced the topic into their commentaries on Peter Lombard's Sentences via this question, and discussed the topic extensively. Often these sources identified contentious issues (e.g., whether or not the sleeper could sin) and enlarged the debate over the cognitive and moral dimensions of the subject.

Despite the many differences between the sources in terms of contexts and purposes, this study identifies a common framework emphasising the unique and crucial role of the sleeper's mind, around which the writers built their analyses of the phenomenon. While the sources may disagree with one another and approach the subject from different angles, nonetheless there is considerable agreement in their recognition that the sleeper's mental processes were essential in understanding the unusual physical act of emitting seed while asleep. In doing so, they explore the psychology of sleep and the complex relation between the waking and sleeping states.

At this point, two caveats should be noted. Firstly, it should already be apparent that the discussions of nocturnal pollution largely assume a male model; as an almost inevitable consequence, they invoke a heterosexual paradigm of male sexual desire for a woman. There are a few, rare references to women as nocturnal polluters (see the discussion of virginity,

\footnotetext{
${ }^{6}$ Gratian, Decretum, 1.9-11.
} 
below), but the focus is overwhelmingly on men as sufferers from nocturnal pollution. Secondly, the phrase pollutio nocturna appears consistently across the different sources, even those which are not concerned with moral implications, such as the medical and natural philosophical materials. The term even applies to Pseudo-Gregory's first causal category, an emission arising from natural superfluities, for which there is no implication of sin. In this sense, it is best to treat the term 'pollution' as largely synonymous with emission and as sometimes devoid of moralised meaning.

While we can never know the frequency with which nocturnal pollutions actually occurred, it is clear from various statements that a number of authors considered the phenomenon problematic and urgent enough to warrant considerable discussion. Like Cassian, there is a sense of anxiety that the uncontrollability of the sleeper's mind and body could affect anyone, even the most devout of Christians. ${ }^{7}$ Robert of Flamborough in his early thirteenth-century book for confessors reduces the discussion to a very brief dialogue in which the penitent's participation consists of a single word: when asked if he experiences nocturnal pollutions and, if so, how often, the penitent pithily notes, 'frequently' (frequenter). ${ }^{8}$ Most importantly for our purposes, several sources indicate not only that nocturnal pollution was common, but also that its most frequent cause was the ability of the mind, especially the imagination, to produce the dream imagery which would induce an emission. In his dour assessment of human life, De miseria humanae conditionis, written in the 1190s before he took up the Papal throne, Pope Innocent III discusses the terror which

\footnotetext{
${ }^{7}$ Aquinas invokes Cassian's stories of holy men who are deceived by the Devil into polluting themselves on the night before they were to take up communion, as a means of keeping even the holiest individuals from the saving grace of the Eucharist. See Aquinas, Super Sent. lib. 4, d.9, q.1, a.4, q.2, conclusio; vol. 4, pp. 388-9 ; and Aquinas, ST 2-2, q.154, a.5, conclusio, and 3a, q.80, a.7, conclusio.

${ }^{8}$ Robert of Flamborough, Liber poenitentialis, ed. J.J. Francis Firth (Toronto: Pontifical Institute of Medieval Studies, 1971), 298.
} 
can occur in dreams and notes that filthy (turpes) images appear, again, 'frequently'. ${ }^{9}$ Albert the Great also notes that nocturnal pollutions induced by phantasms in the imagination are common, more so than pollutions arising from purely physiological causes. ${ }^{10}$ Commonplace or not, nocturnal pollutions appeared regularly in a wide variety of sources as a subject of concern which centred on the mental, physical and moral implications of sexual desire.

\section{Imagining desire: the sleeping mind and the imagination}

In order to understand twelfth- and thirteenth-century concepts of nocturnal pollution, it is useful to begin with the contemporary understandings of sleep. The mental status of the sleeper is best revealed by looking at the contemporary views of the resting brain's physiology, which was defined as radically different from that of the waking person. From the beginning of the thirteenth century, the understanding of the sleeper was crystallised in the Aristotelian writings of natural philosophers, physicians and others heavily dependent upon the Stagirite's thought. ${ }^{11}$ But even before the introduction of the New Aristotle, the sleeper's unique physical and mental status had been articulated by philosophers and theologians alike. The sleeper's bodily functions were thought to turn inward, away from external physical movement and toward internal processes of digestion and replenishment which occurred in the stomach, liver and heart. The sleeper's body was externally cold and still because all heat and movement were needed for the nightly transformation of food and drink into the various liquids, most importantly blood, which were necessary to keep the body

\footnotetext{
${ }^{9}$ Lotharii cardinalis (Innocentii III), De miseria humane conditionis, ed. Michele Maccarrone (Rome: In adebus Theasauri Mundi, 1955), 31 (1.24): 'Apparent enim frequenter in sompniis turpes ymagines [ymaginaciones], ex quibus per illusiones nocturnas non solum corpus polluitur, sed anima maculatur.'

${ }^{10}$ Albert, Summa de creaturis, in Opera omnia, ed. E. Borgnet. 38 vols. (Paris: Apud Ludovicum Vivès, 18909), 35: 364a (q. 43).

${ }^{11}$ Fernand Van Steenberghen, Aristotle in the West: The Origins of Latin Aristotelianism (Louvain:

Nauwelaerts, 1955).
} 
balanced. ${ }^{12}$ The often-reiterated argument stated that, within the sleeper's body, there was an intensification of the natural virtues - that is, the powers which maintained the body's functioning and were associated with the liver - while there was relaxation and dullness of the animal virtues or mental functions, associated with the brain. ${ }^{13}$

Central to this Aristotelian view was the idea of sleep as an absence or negation: the sleeper generally could not move, could not sense or respond to immediate external phenomena and could not think rationally. That is, the sleeping state was, in a number of essential ways, the negation of the waking state. Aristotle's De somno et vigilia, often read and commented upon from the thirteenth century onward, created a binary opposition between the states of wakefulness and sleep. ${ }^{14}$ Medieval natural philosophers understood the sleeper to be a passive creature, closed off from the world around him and incapable of voluntary motion.

Just as the sleeper's body had largely shut down and turned inward, so his mental functioning was also largely absent. The most common medieval understanding of the brain, inherited from Galen and the classical world, was built around a series of three chambers or ventricles within which all cognitive functioning occurred. At the front of the brain, the organ of common sense received all the perceptions from each of the five senses; these were retained, transformed into sense impressions and then gathered together by the imagination (or fantasy), directly behind the common sense in the first ventricle. These impressions, often referred to as images although they included other forms beyond the visual, were then interpreted in the middle ventricle. This ventricle housed human rational functioning, which

\footnotetext{
${ }^{12}$ For the Latin versions of the texts, see Aristotle, De somno et vigilia liber, adiectis veteribus translationibus et Theodori Metochitae commentario, ed. H.J. Drossaart Lulofs (Leiden: Burgerskijk and Niermans, 1943) and De insomniis et De divinatione per somnum: A New Edition, ed. H.J. Drossaart Lulofs (Leiden: Brill, 1947). See also Hagar Kahana-Smilansky, 'The Mental Faculties and the Psychology of Sleep and Dreams', in Science in Medieval Jewish Culture, ed. Gad Freudenthal (Cambridge: Cambridge University Press, 2011), $230-54$.

${ }^{13}$ B. Lawn, ed., The Prose Salernitan Question (Auct. F.3.10). Acutores Britannicai Medii Aevi 5 (London: Oxford University Press for the British Academy, 1979), 358-9 (K8).

${ }^{14}$ H. Wijsenbeek-Wijler, Aristotle's Concept of Soul, Sleep and Dreams (Amsterdam: Hakkert, 1978).
} 
allowed for cogitation and deliberation. The final, posterior ventricle housed the memory, more specifically a form of long-term recollection, since the imagination also included some aspects of short-term recollection. ${ }^{15}$ Despite a number of variations, this tripartite model allowed for a schematic understanding not only of the geography of the brain but also of the process of cognition itself: sensations entered the brain via the senses, were then impressed on the imagination, interpreted in the rational faculty and finally retained in the memory.

In sleep, however, this model of brain functioning was severely reduced and restricted. Because the senses during sleep did not respond to external stimuli, the common sense was inactive. The middle and posterior ventricles of the brain were also assumed to be inoperable. As a result, the sleeper was not capable of rational thought. Crucially the incapacity included the ability to distinguish between reality and fantasy, and the ability to make choices. In short, deliberation and free will were not available to the sleeper. ${ }^{16}$

In the midst of these limits and absences of sleep, while the external body was passive and much of the brain was inactive, the only part of the brain which continued to function was the imagination. It was not simply active but, as the only part of the mental process still functioning in sleep, it ruled the brain and its control was largely unopposed. ${ }^{17}$ As a result, the imagination was identified as the primary mechanism by which nocturnal pollutions could arise. The following section studies the process by which many nocturnal pollutions were thought to occur: from the sensations and emotional responses of the waking state through their recollection via the sleeper's imagination and the various mental and physical responses of the sleeping state. The process raises questions about the crucial role played by the

\footnotetext{
${ }^{15}$ E. Ruth Harvey, The Inward Wits: Psychological Theory in the Middle Ages and the Renaissance (London: Warburg Institute, 1975); Mary Carruthers, The Book of Memory: A Study of Memory in Medieval Culture. 2nd edn. (Cambridge: Cambridge University Press, 2008), 60-8 and passim.

${ }^{16}$ Aquinas, Super Sent., lib. 4, d.9, q.1, a.4, q.1, conclusio; vol. 4, p. 386, par. 142: 'In somno autem sensus ligati sunt; et ideo nullum judicium animae est liberum, neque rationis neque sensus communis.'

${ }^{17}$ See, inter alia, Murray Wright Bundy, The Theory of Imagination in Classical and Mediaeval Thought (Urbana: University of Illinois, 1927), and M. Fattori and M. Bianchi, eds., Fantasia-Imaginatio: Atti del V Colloquio del lessico intellettuale europeo (Rome: Edizioni del Ateneo, 1988).
} 
imagination in the interactions between waking and sleeping, and between mind and body. How did the illusions and sexual images appear in the sleeper's mind without any ability to control either the thoughts or their corporeal consequences? How did the mind assume the images to be real and how did the body then respond to them?

\section{Relics of thought: sensory perceptions and impressions}

There was general recognition that nocturnal pollutions arising from the imagination were based around the transformation of sense perceptions into sense impressions, which became the basis for the dream imagery experienced by the sleeper. Such dreams were seen as radically different from the various other types of sleep images as understood in medieval dream theories. As Stephen Kruger has pointed out, a variety of dream theories coexisted in the central Middle Ages, but they all held in common a belief in a hierarchy of dreams. Macrobius' five types of dreams, for example, distinguished divinely-inspired dreams at the top of the hierarchy from purely personal, somatic and emotion-based dreams at the bottom. It is into this last category, of course, that nocturnal pollutions solidly fitted. ${ }^{18}$ Caesarius of Heisterbach in his Dialogue of Miracles inserted Pseudo-Gregory's tripartite causal explanation of nocturnal pollutions into a larger taxonomy of all dreams by first discussing Pseudo-Gregory's various bodily and mental causes of dreams and then noting simply that other dreams are revelations of the Holy Spirit. While they did not arise from one's waking fears, hopes and desires, even prophetic and divine dreams were often thought to involve the imagination: God or his messenger interacted with the sleeper via the imagination. ${ }^{19}$ Dreams

\footnotetext{
${ }^{18}$ Macrobe, Commentaire au songe de Scipion, ed. Mireille Armisen-Marchetti (Paris: Les Belles lettres, 2001), 10-13 (1.3.1-11); William Harris Stahl, Commentary on the Dream of Scipio by Macrobius (New York: Columbia University, 1952), 87-92. Stephen F. Kruger, Dreaming in the Middle Ages (Cambridge: Cambridge University Press, 1992), chapter 4; and Thomas Ricklin, Der Traum der Philosophie im 12. Jahrhundert: Traumtheorien zwischen Constantinus Africanus und Aristoteles (Leiden: Brill, 1998), 107-20.

${ }^{19}$ Caesarius of Heisterbach, Dialogus miraculorum, ed. Josephus Strange (Cologne: J.M. Heberle, 1851), 8.4, vol. 2.83.
} 
and their content could be pleasant or terrifying, uplifting or morally problematic, divine insights or demonstrations of base bodily desires.

The mind and particularly the images it produced while dreaming were central to most discussions of nocturnal pollution. The letter attributed to Gregory the Great argues that mental images played a crucial role in all forms of nocturnal emission, even those entirely built on humoral superfluities. The letter emphasises two types of minds, not only that of the sleeper but also that of the cleric whose task was to judge a specific instance of pollution: 'one should use discretion, by which it ought subtly to be considered (pensari) from what thing this occurred in the sleeper's mind. ${ }^{20}$ Pseudo-Gregory suggests that even the first category of nocturnal emissions - those arising from a natural humoral imbalance - were connected to the mind and not just the body.

It is in discussions of Pseudo-Gregory's third type of pollution, those involving lustful images, that the mental state of the sleeper received the greatest attention and the psychological implications of nocturnal pollution were being worked out in greater detail. Recognition of the psychology of sleep and the moral danger of dreams appeared prominently in many texts of the late twelfth and thirteenth centuries, particularly in confessional literature. Thomas of Chobham in his Summa for confessors, written in the 1210 s, notes that 'filthy imagination will disturb the mind, as it often happens that, while asleep, one has filthy imaginations of sexual intercourse. ${ }^{21}$ For Guy of Southwick, writing in his book for confessors in the early 1200s, such disturbances were typical of the human mind,

\footnotetext{
${ }^{20}$ Bede, EH 1.27; Gratian, Decretum, dist. 6, c. 1-3; Johann Friedrich von Schulte, ed., Die Summa des Paucapalea über das Decretum Gratiani (Giessen: Emil Roth, 1890), 12: 'Sed est in eadem illusione valde necessaria discretio, quae subtiliter pensari debet ex qua re accidat menti dormientis.'

${ }^{21}$ F. Broomfield, ed., Thomae de Chobham Summa confessorum. Analecta medievalia Namurcensia 25 (Louvain: Éditions Nauwelaert, 1968), 331 (2.1a.2): 'Et magnum quidem peccatum est precipue si in polluendo mentem turpis imaginatio concusserit, sicut sepe contingit in dormiente quod turpes habet imaginationes coeundi.'
} 
which while awake or asleep could be easily distracted by recurring memories (moral, immoral or even inconsequential) and noted that it frequently happened to him. ${ }^{22}$

But it was not just any sense perception from the waking state which would resurface in the sleeper's mind and produce a nocturnal emission. There was general agreement that what set everything in motion was a specific encounter with someone whom the individual found attractive. This could simply be the sight of the other person or a more extensive interaction involving talking with or even touching the object of desire. The initial interaction or sighting and the sexual attraction it engendered then led to further thoughts about the woman, whether she were present or not. Thomas of Chobham notes that the pollution occurred not simply from talking with a woman but also from thinking about her afterwards. ${ }^{23}$ Contact with and/or sight of the object of desire produced a powerful reaction which would be retained in the imagination as a particularly vivid image or impression. Moreover this kind of impression was more than just a passing thought; it was a type of thought which was identified as 'filthy' or 'lustful' (praua cogitatio ... et voluptaria), as Peter of Poitiers notes in his early thirteenth-century Summa de confessione. ${ }^{24}$ The sense perceptions of sight, hearing and touch led to responses of desire and further contemplation of the object of desire.

The waking thought which could produce a nocturnal pollution included one further attribute: it often involved a temporal sense of prolonged reflection on the memory of the beloved, as seen in the phrase morosa cogitatio, 'a lingering thought.' Bonaventure in his Speculum disciplinae discusses a 'lingering delight' induced by the imagination (delectationis

\footnotetext{
22 D.A. Wilmart, 'Un opuscule sur la confession composé par Guy de Southwick vers la fin du XIIe siècle', Recherches de Théologie Ancienne et Médiévale 7 (1935): 345: 'Contingit enim multis, michi utique et mei similibus.'

${ }^{23}$ Thomas of Chobham, Summa confessorum, 331-2 (2.1a.3).

${ }^{24}$ Peter of Poitiers (Petrus Pictaviensis), Summa de confessione, ed. Jean Longère. CCCM 51 (Turnhout: Brepols, 1980), 18 (c. 13).
} 
morosae). ${ }^{25}$ In the Secrets of Women, a natural-philosophical text written in the late thirteenth century and wrongly attributed to Albert the Great, nocturnal pollutions are attributed to 'too much concentration on shameful things or too much talk' ${ }^{26}$ The Montpellier physician Bernard of Gordon, writing in his Lilium medicine completed in 1304, emphasises the excessive and lingering nature of the waking desire which could lead to a nocturnal pollution: 'a desire of long duration for the inordinate love of a woman'. ${ }^{27}$ In this awkward phrasing, Bernard identifies two forms of excess which can lead to nocturnal pollutions, an excess of love and an excess of time. The implication here is that the temporality involved in the notion of lingering makes it more likely that the thought would be impressed strongly on the imagination and later resurface in the sleeper's mind, once its waking control mechanisms were inoperative, thus triggering a nocturnal emission. Albert the Great identifies the same idea of concentrated contemplation when he refers to a nocturnal pollution as 'the sign of an earlier fixed (fixae) filthy thought'. ${ }^{28}$ Whether it was fleeting or prolonged, the interaction with the woman stands out among all of the sense impressions in the sleeper's imagination precisely because it has been supplemented and reinforced by the waking person's continued rumination about the event.

The dual focus on sight of and prolonged thought about the object of desire finds an important and striking parallel in the tradition of courtly love as it developed in the twelfth

\footnotetext{
${ }^{25}$ Bonaventure, Speculum disciplinae, in Doctoris Seraphici S. Bonaventurae Opera omnia, vol. 8 (Quaracchi: Ex typographia Collegii S. Bonaventurae, 1898), 639b (c. 34). See also Aquinas, ST 1-2, q.74, a.6; Peter of Poitiers, Summa de confessione, 18 (c. 13); and Albert, Commentarii in IV sententiarum, in Opera omnia, ed. Borgnet, 29: 235a (9b, art 10, solutio), for a reference to 'lingering delight in a preceding thought.' ${ }^{26}$ Albertus Magnus de secretis mulierum cum commento (Venice: Jo. Alvisium de Varisio, 1501), ff. bii-r: 'Secundo modo fit ex nimia cogitatione turpi uel locutione tunc de nocte fit pollutio' [Commentary B]; see Helen Rodnite Lemay, trans. Women's Secrets: A Translation of Pseudo-Albertus Magnus' De secretis mulierum (Saratoga Springs, NY: State University of New York Press, 1992), 75.

${ }^{27}$ Bernard of Gordon, Practica Gordonij dicta Lilium medicine, (Venice: Bonetus Locatellus, 1498), f. 88va (7.4): 'Quarta causa est concupiscentia diuturna circa amorem inordinatum mulieris.'

${ }^{28}$ Albert, Commentarii in IV sententiarum, in Opera omnia, ed. Borgnet, 29: 235a (9b, art 10, sol): 'Alio modo fit pollutio peccatum ex cogitatione, scilicet quando aliquis cogitat de aliqua singulariter, et postea somniat se coire cum eadem: et tunc est signum fixae cogitationis praecedentis in turpi.'
} 
and thirteenth centuries. The mechanisms by which a courtier was thought to fall in love corresponded directly to these two causes of nocturnal pollution and the theory of mind which underlay them. In the 1180s, Andreas Capellanus began his famous treatise De amore with a definition of love which echoed the cognitive (rather than somatic or external) causes of nocturnal pollution. Andreas defined love as a passio, that is, a disease, condition or suffering which arose 'from the sight of and immoderate thought about the form of the opposite sex ('ex visione et immoderata cogitatione formae alterius sexus').' ${ }^{29}$ This association of a sense perception and a mental preoccupation - note the negative adjective denoting excessive cogitation - closely parallels the discussions of nocturnal pollution. Andreas frequently mentions sight and especially thought; the noun cogitatio and verb cogitare appear 10 times in the brief opening chapter of Book 1 of De amore. The very process of falling in love as understood in the twelfth century involved the same ingredients as those which led to a nocturnal pollution.

The vision of the object of desire and the libidinous thoughts about her while awake were retained in the imagination and, because of the deep impression caused by the powerful feeling of desire, became likely to reappear in the sleeper's dreams. In his early thirteenthcentury treatise on the sacraments, Guido de Orchellis provides a useful correlation between the waking and sleeping states: when a man sees a woman and desires her by day, an image of that woman comes to his mind by night, and leads to a nocturnal emission. ${ }^{30}$ The reference to sight is important here: the term imaginatio refers etymologically to the sense of sight and serves to reinforce a notion of the priority of vision over the other senses. Sight was usually

\footnotetext{
${ }^{29}$ Andreas Capellanus, De amore, ed. E. Trojel (Copenhagen: Libraria Gadiana, 1892), pp. 3-4 (1.1). Mary Frances Wack, Lovesickness in the Middle Ages (Philadelphia: University of Pennsylvania Press, 1990). On the pivotal role of sight in the love poetry of the thirteenth century, see Dana E. Stewart, The Arrow of Love: Optics, Gender, and Subjectivity in Medieval Love Poetry (Lewisburg: Bucknell University Press, 2003).

${ }^{30}$ Guido de Orchellis, Tractatus de sacramentis, ed. Damien and Odulphus van den Eynde (St Bonaventure, NY: Franciscan Institute, 1953), 95 (93): 'quando viderit de die quis mulierem ad concupiscendum eam, si de nocte quaedam imaginatio qua illudatur illi occurrerit.'
} 
identified as having triggered desire in the waking state, so much so that a simulacrum of that waking vision resurfaces in dreams with similar libidinous consequences. Aquinas notes that 'dreams have their causes in waking people's imagination', a phrase which shifts the focus from the initial sight of the beloved to the power of the imagination to retain the image and to reproduce it as a dream. He notes that, while the senses which were the origin of the thought (cognitio) may be bound in sleep, the imagination was not and thus it 'supplie[d] the images (species) of things to [the sleeper]'.31

For the sleeper, the imagination acted as the essential link between the prior waking state and sleep. Despite the various ways in which they described the phenomenon, the sources were in agreement that 'remnants of thought' (reliquie cogitationis) provided some continuity between the two states, allowing for residual images, ideas and emotions to resurface in dreams. Isidore of Seville, in his Sentences (3.6.6), had drawn a connection between waking cognition and dream imagery: 'for often what we think during the day, we recall to mind at night [i.e. in our sleep]. ${ }^{32}$

Found in natural-philosophical as well as religious materials, the argument that some vestiges of the waking experience returned in sleep had both positive and negative implications. Guy of Southwick, in his late twelfth-century tract on confession, invoked the biblical origins of the phrase 'remnants of thoughts': it appears in Psalm 75:11, 'For the thought of man shall give praise to thee, and the remainders of thought will keep holiday for thee' (Douay-Rheims translation). ${ }^{33}$ The biblical passage does not refer to sleep, but Guy interprets it in this context and with greater ambivalence than the Psalmist had perhaps

\footnotetext{
${ }^{31}$ Aquinas, Super Sent. lib. 4, d.9, q.1, a.4, q.1, conclusio; vol. 4, p. 386, par. 143: 'somnia habent causas imaginationis vigilantium', and ad 2: 'imaginatio ejus non ligetur, quae immediate ei species rerum subministrat.'

${ }^{32}$ Pierre Cazier, ed., Isidorus Hispalensis Sententiae. CCSL 111 (Turnhout: Brepols, 1998), 219-20 (3.6.13): 'nam saepe quae in die cogitamus, in noctibus recognoscimus.'

${ }^{33}$ Septuagint version of Psalm 75:11: Biblia sacra iuxta vulgatam versionem, ed. Robert Webb (Stuttgart: Württembergische Bibelanstalt, 1975), vol. 1, p. 862; 'Quoniam cogitatio hominis confitebur tibi, et reliquiae cogitationis diem festum agent tibi'.
} 
intended: while good thoughts can continue after their completion, bad thoughts can equally return in sleep and as a consequence endanger our souls. Guy specifically cites nocturnal pollutions as evidence that morally problematic thoughts and feelings can return: whether in waking or sleeping, our minds can be disturbed by any thoughts or concerns upon which we might have dwelt earlier, whether it involved thinking 'often and for a long time about something unclean ${ }^{34}$ or being overly occupied by some work or a worry. As a result, these mental preoccupations creep insidiously back into our minds: even when we are engaged in religious devotions,

the remnants of prior thoughts rush in inappropriately and frequently turn us from the correct intention or work. Even when we sleep, so many phantasms in dreams re-present the remnants of thoughts to our soul that they both disturb the spirit with carnal delight and stain the flesh with an actual pollution. ${ }^{35}$

The passage encapsulates the argument that the mind influences body and soul: the past comes back to haunt the sleeper's present, as the relics of earlier experiences return via phantasms, images arising from the imagination's storehouse of sensory impressions, and can at times produce negative consequences, including nocturnal emissions.

Echoing the idea of remnants of thoughts returning in sleep, Hildegard of Bingen, in her medical text Causae et curae, sees a direct correlation between the quality of one's waking thoughts and the quality of dreams: 'Many times a man is weighed down in his sleep by the thoughts and beliefs and wishes which occupied him while awake, and sometimes in dreams he is raised like yeast, which raises the mass of the flour, whether those thoughts be

\footnotetext{
${ }^{34}$ Wilmart, 'Guy de Southwick', 345: 'cum inmundum aliquid diutius et sepius cogitamus.'

${ }^{35}$ Wilmart, 'Guy de Southwick', 345: 'etiam cum aliud intendimus et aliud agimus, uerbi gratia legimus, psallimus uel oramus, reliquie cogitationis precedentis inportune se ingerunt et a recta intentione vel opere frequenter auertunt. Insuper etiam cum dormimus, tanta sompniorum fantasmata reliquie cogitationum anime representant, ut et spiritum carnali delectatione concutiant et carnem actuali pollutione coinquent.'
} 
good or bad. ${ }^{36}$ The return of daytime mental activity in sleep creates a contrast of burdensome negative dreams versus uplifting positive visions. Hildegard and others argued for a direct correspondence between the waking state, particularly the mental activity of the waking state, and the world of dreams. Hildegard's yeast metaphor is a bit awkward; the usual argument states that morally positive dreams elevate the individual while morally negative dreams would diminish and thus lower him. But the passage reminds us that dreaming is a morally neutral state, and can produce good and bad dreams with positive or negative implications. The Macrobian taxonomy of dreams identified precisely this issue: lofty and prophetic dreams had divine origins while the more prosaic and earthly dreams had largely somatic and psychological causes. The dilemma with nocturnal emissions lay in the moral implications of the sleeper's dream imagery and bodily response. Aquinas alters the notion of mental remnants by connecting them with the soul as much as with the mind. He notes that it is common for nocturnal pollutions to arise 'out of thoughts of carnal vices' accompanied by desire, from which 'there remains a certain vestige and inclination in the soul, so that through his imagination the sleeper is induced to assent to the acts from which the pollution follows. ${ }^{37}$ For Aquinas, the remnants have been transformed from thoughts into a propensity to desire and to fulfil that desire, an important shift from the passive replaying of images to a more active yearning of the soul, about which we will say more in the next section.

\section{Dream worlds: phantasy as reality}

\footnotetext{
${ }^{36}$ Hildegard, Causae et curae, ed. Laurence Molinier (Berlin: Akademie Verlag, 2003), 122 (165): 'Nam multotiens cogitationibus et opinionibus atque uoluntatibus, quibus homo uigilans occupatur, hiis etiam et in somnis grauatur, et in eis interdum ita eleuatur ut fermentum, quod massam farine eleuat, siue cogitationes ille bone siue male sint.'

${ }^{37}$ Aquinas, ST 2-2, q.154, a.5, conclusio: 'Contingit autem magis pollutio nocturna ex cogitatione carnalium vitiorum quae fuit cum concupiscentia talium delectationum, quia ex hoc remanet quoddam vestigium et inclinatio in anima, ita quod dormiens facilius inducitur in sua imaginatione ad assentiendum actibus ex quibus sequitur pollutio.'
} 
One aspect of these residual images which appears often in the various literatures is the dreamer's belief in the reality of the dream. The vividness and verisimilitude of dreams was (and is) a recognised trait common to oneiric experiences: the realness of prophetic dreams reflected the belief that they were truthful and revelatory, brought by one of God's emissaries. In contrast, more earthly, somatic dreams might reveal something real about the dreamer's body or mind, but ultimately they consisted of phantasms, illusions which could confuse or deceive the sleeper into believing they were real. In the case of nocturnal pollutions, the sources generally agreed that the sleeper accepted the dream vision as real and experienced it as such. In the medical tradition this can be seen in one of the early translations of the Arabic medical tradition. Constantinus Africanus in his Viaticum, written in the second half of the eleventh century, describes the sleeper's experience of the dream, and the belief that the object of desire is actually present: 'in that [pollution] which comes from desire (concupiscentia), the soul imagines the beloved person as if she is next to him, whence nature is moved to coitus so that he has a pollution; sometimes truly a man sees a woman and desires her, and when he sleeps he imagines himself as if he sleeps with her.' ${ }^{38}$ In using the phrase 'as if' (quasi) twice in reference to the imagined interaction, Constantinus is keen to emphasise the perceived realness of the dream to the sleeper, while at the same time acknowledging to his readers that it is only a fiction enacted inside the sleeper's brain.

The twelfth-century Cistercian treatise De spiritu et anima expresses the same idea of the dream world's ability to appear real to the sleeper: 'images of corporeal things' often appear to the dreamer in such a way that 'he cannot distinguish between sleepers' visions and the true intercourse (commixtionem) of waking people, and so the flesh is immediately

\footnotetext{
${ }^{38}$ Constantinus, Viaticum, in Omnia opera Ysaac in hoc volumine contenta (Lyons: in officina Johannis de Platea, 1515), f. 164rb (6.4: De effusione spermatis in somno): 'in ea enim que ex concupicentia, imaginatur anima personam amatam quasi sit vicina, vnde ad coitum mouetur natura vt pollutionem faciat.' Note the religious terminology in the reference to the soul and the use of 'concupiscentia', with its Augustinian implications.
} 
moved. ${ }^{39}$ The author stresses the vividness of the dream experience: the dreamer's mind is convinced that what it sees is real, and his body responds accordingly in a form of virtual or imagined intercourse. It is left unclear if the body performs a sort of erotic pantomime by simulating sexual intercourse or if only the mind does so. The author points to the imagination's power both to simulate reality and consequently to invoke an emotional response; at the same time, he identifies the sleeper's inability to resist responding both emotionally and physically. These two distinct features of dreaming - the passive recollection of prior sensory perceptions as a form of present reality, and the mental and bodily response to it - were perceived to be essential for the production of nocturnal pollution.

Medieval theories of mind provided a ready-made explanation for the sleeper's mental confusion. Aquinas notes the dreamer's delusion and absolute conviction that what he sees is real, but explains this as a by-product of sleep itself: 'In sleeping, reason does not have free judgement; there is no sleeper who does not turn his mind (intendat) to certain likenesses or phantasms just as he would to the things themselves. ${ }^{40}$ Aquinas invokes Augustine's passage from the De Genesi ad litteram (Literal Meaning of Genesis), in which the bishop of Hippo had observed that the sleeper could not distinguish the phantasia (dream scenario) from actual sexual intercourse. ${ }^{41}$ Albert the Great had similarly indicated that the sleeper blurs the distinction between the real object (res) and the image (species or imaginatio). ${ }^{42}$ Because the rational faculty was not functioning, the sleeper had lost any ability to discern signifier from signified, fiction from truth, fantasy from reality.

\footnotetext{
${ }^{39}$ De spiritu et anima, printed among the works of Augustine, in Sancti Aurelii Augustine Hipponensis episcopi, Opera omnia, vol. 6, ed. J.-P. Migne. PL 40 (Paris: J.-P. Migne, 1841), col. 796: 'Unde saepe imagines rerum corporalium tanta illis expressione praesentantur in somnis, quanta ipsa corpora praesentantur vigilantibus, ut inter visionem dormientium et veram commixtionem vigilantium non discernatur; sed continuo eis caro moveatur.' See the translation in Bernard McGinn, trans., Three Treatises on Man: A Cistercian Anthropology (Kalamazoo, MI: Cistercian Publications, 1977), 216-17. I have altered McGinn's rather free translation.

${ }^{40}$ Aquinas, ST 2-2, q.154, a.5, conclusio: 'In dormiendo autem ratio non habet liberum iudicium, nullus enim est dormiens qui non intendat aliquibus similitudinibus phantasmatum velut rebus ipsis.'

${ }^{41}$ Aquinas, ST 3, q.180, a.7, quoting De Genesi ad litteram, 12.15 [31]; vol. 2, pp. 378-80.

${ }^{42}$ Albert, De coelesti hierarchia, in Opera omnia, ed. Borgnet, 14: 35a-b (2.4).
} 
Closely connected to the idea of the realness of erotic dreams is a difficult passage in Pseudo-Gregory's letter which received a considerable amount of attention from twelfth- and thirteenth-century commentators: a reference to what the sleeper sees in his dream as 'true images' ('tempted by uncleanness, he is stained in his thoughts by true images', 'tentatus immunditia veris imaginibus in cogitatione inquinatur'). The phrase is paradoxical due to the implications of the term 'images'; as signs of something else which appear in the mind, they hold a very different (and usually a lesser) ontological status and claim to truthfulness than the object they represent. Canon lawyers in particular explored this phrase and developed two competing interpretations of it in the later twelfth and early thirteenth centuries.

One interpretation acknowledged that the imagination deceived the sleeper into accepting the existence of something which was not really there, but considered the dream image to be true in the sense that it referred to a tangible object outside the dreamscape. In his influential Summa on the Decretum completed 1187-90, Huguccio indicates that the images were true because the referent - the object of desire which was simulated or signified by the dream image - was real, as were the individual's earlier sense perceptions and any interactions he may have had with the object of his desire. For Huguccio, the reality or truth of the actual interaction with, perception of, and emotional reaction to the beloved outweighed the fact that the referent was no longer present and existed as only an image in the sleeper's mind. When glossing the same phrase, the Parisian Summa Animal est substantia, dating to the early thirteenth century, continued this argument by equating the images with waking sense perceptions: they were true because they were ultimately 'images one had while awake, when he thought about someone and desired her and committed adultery with her in his heart'. ${ }^{43}$ This argument follows that of Isidore of Seville, who had

\footnotetext{
${ }^{43}$ Huguccio Pisanus, Summa decretorum, ed. Oldrich Prerovsky (Vatican: Biblioteca Apostolica Vaticana, 2006), (dist. 6); Summa Animal est substantia, ed. E.C. Coppens, 104 (dist. 6, c. 1), at
} 
similarly blurred the distinction between the real and the imagined when he noted that the 'images of lust' which often appear in our minds as we sleep, are images 'which we had in truth entertained', i.e. earlier when we were awake. ${ }^{44}$ The waking state was seen as holding a verifiable truth-claim which was not possible in non-prophetic dreaming; according to this logic, erotic dreams were only true inasmuch as they reflected the sensory and emotional perceptions of the prior waking state.

The other interpretation of the phrase 'true images' also acknowledged the problematic nature of images in sleep but ultimately emphasised the power of the sleeper's mind over his body. Another canon law text dating from the late twelfth century, the Summa 'Omnis qui iuste iudicate' or Summa Lipsiensis, interpreted the phrase by focusing on the consequences rather than the causes of the images. The Summa glossed the phrase 'true images' in this way: 'through the effect of pollution; thus the mind truly, that is, in effect (vere, idest efficaciter), endures the images of defilement, when, through what is seen or done in dreams, the flesh is defiled without feeling.' The author mentions the physical evidence of pollution but prioritises the role of the imagination, which causes 'that which is seen and done in dreams' and leads to the pollution. ${ }^{45}$ Note that we are dealing with a double pollution here: a mental defilement leads to a further, physical defilement. Here the images are true because the flesh responds to them, and the sleeper imagines he is engaged in actual intercourse with the object of desire. The body and its seminal expulsion paradoxically serve as proof of the 'truth' of the illusions within the sleeper's mind. The images may have no

http://www.medcanonlaw.nl/Animal_est_substantia/Distinctiones.html: 'veris ymaginibus. Idest habitis dum vigilat, quando enim aliquis cogitat de aliqua et concupiscit eam et iam mechatus est eam in corde suo.'

${ }^{44}$ Cazier, ed., Isidorus Hispalensis Sententiae, 219-20 (3.6.13): 'Luxuriae quippe imagines, quas in veritate gessimus.'

${ }^{45}$ Rudolph Weigand, Peter Landau and Waltraud Kozur, eds., Summa 'Omnis qui iuste iudicat' sive Lipsiensis,. 3 vols. (Vatican: Biblioteca Apostolica Vaticana, 2007), 1: 24 (dist. 6, c. 1): 'Veris ymaginibus, i.e. per effectum pollutionis certis; tunc enim solum inquinationis imagines vere i. e. efficaciter mens patitur, cum ex eo, quod in somnis videtur vel agitur, caro insensibiliter fedatur.' See also Stephen of Tournai, Die Summa über das Decretum Gratiani, ed. Johann Friedrich von Schulte, (Aalen: Scientia, 1965), 15; Rufinus von Bologna, Summa Decretorum, ed. Henrich Singer (Paderborn: F. Schöningh, 1902), 18. 
substance but they have a power which is demonstrably true as seen in their physical consequence: the pollution itself. The emission of semen serves as proof that the images had invaded the sleeper's mind and aroused his passion; that is, the author of the Summa uses the pollution itself as proof that the sleeper's reactions to the images were real, even though there was no actual sexual encounter. The two interpretations of 'true images' look at different aspects of the process - the causes and effects of the imagination's influence, that is, the sight which led to the dream image and the ejaculation which ensued from the same image - but both emphasise the role of the imagination as the sleeper's intermediary between waking thoughts and night-time bodily movements.

\section{Sensation and movement in sleep}

While the images may have appeared real to the dreamer, questions persisted about the authenticity of the sleeper's response to those images. In particular, the idea that a sleeper could not sense things (the sleeper appears twice among those nichil sentientes, not feeling or sensing anything, in Huguccio's Summa) called into question the idea that sexual desire could intrude on the sleeper's mind. Despite occasional misgivings, most of the literature argued that the sleeper was capable of various emotional states. In his Summa theologiae, Albert the Great makes it clear that the sleeper can respond emotionally to what he sees in his dreams: claiming he is quoting Aristotle, Albert states that phantasms which appear in sleep 'move sleepers and incite them either to desires (libidines) or fears' ${ }^{46}$ In her collection of mystical experiences, Scivias, Hildegard of Bingen describes a vision in which God himself argues that emotionally the two states of waking and sleeping are parallel: a man can 'burn with

\footnotetext{
${ }^{46}$ Albert, Summa theologiae, in Opera omnia, ed. Borgnet, 33: 398b (tr.18, q. 122); Huguccio, Summa decretorum, 114 (dist. 6, c. 3): 'eadem vi qua moverunt vigilantes, redeuntes ad organa sensuum movent dormientes, et incitant vel ad libidines, vel ad terrores.'
} 
desire as much while asleep as while awake'. ${ }^{47}$ Some writers went further and argued that the sleeper was in fact more prone to sexual yearnings than the waking person. In his early work De creaturis, dating to the 1240 s, Albert bluntly indicates that sleep provides fertile ground for eroticism: 'men are moved to lust more in sleep than in the waking state', ${ }^{48}$ although he does not explain why this should be the case.

The imagination played an ambiguous role in the sleeper's world. Several of the early thirteenth-century natural-philosophical Prose Salernitan Questions argued that the imagination is actually stronger in the waking state than in sleep, but during the waking state the imagination is overwhelmed by the constant barrage of sense perceptions coming from the common sense. In contrast, the sensory quiet which occurs upon entering the state of sleep allows the imagination to exert its influence more clearly. ${ }^{49}$ It is for this reason that the imagination returns to the remnants of the day's activities, those thoughts, emotions and sense impressions which remain in its 'storehouse' or 'treasure room' (thesaurus).

The question of precisely how thoughts became actions, that is, how the sleeper's mind influenced his body enough to induce an ejaculation, was not easily answered, and there is no coherence to the various explanations. For medieval theorists, nocturnal pollution entailed the translation of mental into bodily activity. The process is clear, although the specific mechanics of it are not: a sensory perception and an emotional response while awake eventually return during sleep as a sense impression (image) and desire, which lead to a physical response, the emission of seed. In De coitu, his treatise on male sexuality from the late eleventh century, Constantinus Africanus succinctly explains the mechanisms by which

\footnotetext{
${ }^{47}$ Hildegard, Scivias, ed. Adelgundis Führkötter and Angela Carlevaris (Turnhout: Brepols, 1978), CCCM 43, 2.6.79, p. 293: 'homo ille qui tam dormiendo quam vigilando fortiter in libidine ardet.' Much of the passage actually addresses the issue of avoiding foods which will excite lust in sleep.

${ }^{48}$ Albert, Summa de creaturis, in Opera omnia, ed. Borgnet, 35: 367a-b (q. 43): 'accidit, quod homines plus moventur libidine in somnis, quam in vigilia.'

${ }^{49}$ Lawn, ed., Prose Salernitan Questions, 121-2 (B245, B 246).
} 
nocturnal pollutions arising from the mind occur: 'the images (species) of women, having been seen, give pleasure and, returning to the memory in sleep, bring on pollutions. ${ }^{50}$ That the pollution was the consequence of the imagination's recreation of an earlier experience was not controversial, but how did it come about? Some natural-philosophical and medical authors attempted to identify the precise ways in which this control of mind over body could occur. Albert the Great provided an account that hints at the process by which these nocturnal pollutions arose:

In dreams the imagination sometimes prepares images according to the inclination of nature and desire, and as a result the person whose nature is weighed down by a superfluity of seed or who is in the lust of concupiscence sees images appropriate to such things [i.e. to sexual desire], such as images of women, and thus the member is moved by the image as it would be by the thing itself (sicut ad rem). ${ }^{51}$

We have already encountered the idea that the dream world successfully simulates a waking reality, which is encapsulated in this passage; to the dreamer's mind, the image of the beloved takes on the ontological status of the thing it represents. Here Albert describes the impact of the false image on not just the sleeper's mind but also his genitalia. Albert is not particularly forthright on details, but he notes later that the fantasy (usually synonymous with

\footnotetext{
${ }^{50}$ Enrique Montero Cartelle, ed., Constantini liber de coitu: El tratado de andrología de Constantino el Africano (Santiago de Compostela: Secretariado de Publicaciones de la Universidad de Santiago, 1983), 100 (chapter 5): 'Fiunt quoque polluciones cum species feminarum vise placuerunt et in sompno reducte ad memoriam polluciones commovent.' My translation differs from that of Paul Delaney, 'Constantinus Africanus' 'De Coitu': A Translation,' Chaucer Review 4, no. 1 (1969): 55-65 (58). For other references to the idea of returning the memory, see Cazier, ed., Isidorus Hispalensis Sententiae, (3.6.11); Huguccio, Summa decretorum, 112 (dist. 6, c. 2).

${ }^{51}$ Albert, Summa de creaturis, in Opera omnia, ed. Borgnet, 35: 367a (q. 43): 'in somnis imago praeparat imaginationes secundum inclinationem naturae et desiderii quandoque, et idcirco cujus natura gravata est superfluo seminis, vel qui est in desiderio concupiscentiae, videt imaginationes talibus aptas, sicut imaginationes mulierum, et sic movetur membrum ad imaginationem sicut ad rem.' Note that Albert uses the terms imago and imaginatio in ways opposite to the most common medieval usage. This is a good example of technical terminology which is not entirely static. I have inverted the two terms for the sake of consistency and legibility. Note also that Albert states that even those with an excess of semen will experience erotic images, even if they did not lust after someone while awake.
} 
imagination) produces images and 'the soul commands the virtue which moves and extends the genital member to expel seed. ${ }^{52}$ Elsewhere, while still vague about the actual process, Albert is very clear that the sleeper's imagination could influence and even control the entire body, including the generative organs: 'in sleep, when the form of a woman appears in the imagination, the whole body is moved. ${ }^{53}$ For Bernard of Gordon in his Lilium medicine of 1304, the prolonged nature of the sexual desire of the waking state causes the imaginative virtue (the active power of the imagination or fantasy) to be moved in sleep because of the image of the beloved. The imaginative virtue then commands (precipit) the lower virtues to create and expel the pollution. ${ }^{54}$ The lower virtues here refer to the generative power or virtue, which alongside the nutritive virtue was associated with the liver, while the imaginative virtue was located in the brain. The passage indicates that, without any rational faculties, the imaginative virtue controls not only the brain but also various movements elsewhere in the body. Both Albert the Great and Bernard of Gordon identified and sought to explain the seemingly uncontrollable power of the brain (and thus the imagination) over the rest of the body in sleep.

The medical literature devoted more time to the physical rather than mental causes of the condition, but still made a coherent case for the latter's importance by emphasising the imagination's unique and slightly contradictory status in sleep. In the Prose Salernitan

\footnotetext{
${ }^{52}$ Albert, Summa de creaturis, in Opera omnia, ed. Borgnet, 35: 364 (q. 43): 'Videmus enim frequenter in somnis ad motum phantasiae, quod anima praecipit virtuti moventi et extendenti membra genitalia ad expulsionem superflui seminis, sicut fit in his qui polluntur in somnis.' Note Albert's claim that 'we often see' this in sleep.

${ }^{53}$ Albert, De coelesti hierarchia, in Opera omnia, ed. Borgnet, 14: 111b (4.4): 'sicut patet in somnis, quando repraesentatur forma mulieris in imaginatione, totum corpus movetur.' This brief passage appears in a commentary on Pseudo-Dionysius in a section describing how angels communicate with humans; the imagination was thought to be one of the most important paths by which spiritual creatures do so. See the discussion of the Devil below. The mention of the whole body may also be a reference to the theory of pangenesis, the claim that semen is produced out of each member of the body. See D. Jacquart and C. Thomasset, Sexuality and Medicine in the Middle Ages, trans. Matthew Adamson (Oxford: Polity Pres, 1988), chapter 2.

${ }^{54}$ Bernard of Gordon, Practica Gordonij seu Lilium medicine, f. 205vb (7.4).
} 
Questions, we encounter a question which addresses the difference between the waking and sleeping brain: 'It is asked, since the imagination is stronger in waking than in sleep, why does someone who is sexually aroused emit sperm in his sleep but never while awake?' ${ }^{55}$ In one manuscript, the answer involves the interaction of body and mind as the writer describes the process of creating sperm, a process which, he implies, perfectly coincides with the sleeping states. According to this model, four things are necessary for the production of sperm: imagination, spirit, humour and heat. The author assures us (satis patet) that all four of these elements are active in sleep and thus allow the sleeper to emit sperm. Revealingly, the imagination is identified as the originary cause (primitiva causa), because it is the erotic content of the dream - in which the sleeper imagines a woman or his marital duty - which sets in motion the corporeal actions which lead to ejaculation: the dreamer's imagination allows the animal spirit to move to the genitals, and then to increase the body's heat and to transform bodily moisture into sperm. ${ }^{56}$ The power of the imagination is made explicit here, as the instigator of both the desire and its bodily satisfaction. The implication here is that, through its mental and somatic processes, sleep itself provides the perfect framework for the production of nocturnal emissions, with the imagination acting as catalyst.

The very act of emitting semen in sleep seemed to contradict one of Aristotle's central arguments about sleep: that the sleeping body was passive and should produce no movement. Yet, like sleepwalkers, nocturnal polluters seemed to be active while resting. Aquinas refers to the 'sleeper's act' (actus dormientis), a term which should in Aristotelian terms be an oxymoron. There is some sense that he was aware of the contradiction, as he then sought to provide evidence for his claim. He quoted a passage from Aristotle's Nicomachean Ethics (1.13) to describe the permeability of the borders between the waking and sleeping states: the

\footnotetext{
${ }^{55}$ Lawn, ed., Prose Salernitan Questions, 121 (B245): 'Queritur cum fortior sit imaginatio in vigiliis quam in sompnis, quare quis ad veneria commotus spermatizet in sompnis, in vigiliis nequaquam?'

${ }^{56}$ See Lawn, ed., Prose Salernitan Questions, 121-2 (B246) and 186 (Ba96).
} 
idea that 'certain movements little by little cross from the waking person to the sleeper' meant that the virtuous would have better dreams than the less virtuous. ${ }^{57}$ The choice of this passage is revealing, since it shifts the meaning of 'movement' away from the physical and toward the cognitive. That is, the motion here is a translation of waking experiences into the individual's dream world, a movement of the mind rather than the body. Thought, and in particular the act of recollecting the object of desire in sleep, was a form of movement in itself, one which then induced the movement of the body which resulted in ejaculation. Ultimately, the physical act of emitting semen was a passive consequence of the imagination's free reign over the sleeper's mind; like the sleepwalker, the nocturnal polluter might act and move, but was thought to do so without his own volition as a result of immoral thoughts. It is to the question of morality and sleep that we now turn.

\section{Can the sleeper sin? Moral considerations and the mind at rest}

For theologians, canon lawyers and confessors, medieval theories of mind served as merely a prelude to their greater concern over the nocturnal polluter's moral responsibility. The question was sometimes asked in a very straightforward way: Can the sleeper sin? The question was generally answered in an even more direct manner: No. But as is typical of thirteenth-century scholastic culture, there were disagreements, large and small, over the meaning of the question, leading to a proliferation of further questions. Can a sleeper have sexual desire in sleep but not commit a sin? Can an act committed in sleep be sinful although the sleeper is not liable? Can someone who begins to have a nocturnal emission in his sleep but wakes up in the midst of it be free of $\sin$ ?

\footnotetext{
${ }^{57}$ Aquinas, Quaestiones disputatae de veritate, in Sancti Thomae de Aquino Opera omnia, vol. 22, part 3 (Rome: Editori di San Tommaso, 1976), 830 (28.3.7): 'virtus actus vigilantis relinquitur in operibus dormientium.' On medieval views of the various types of medieval sleepwalkers, see William MacLehose, 'Sleepwalking, Violence and Desire in the Middle Ages', Culture Medicine and Psychiatry 27 (2013): 601-24.
} 
The answer to these further questions was (usually) yes. More importantly for our purposes, the explanations for each of these statements were often intimately connected to the mental state of the sleeper. By the mid thirteenth century, the argument about sin reformulated Pseudo-Gregory's argument in the following way: nocturnal pollution in and of itself (secundum se) was not a sin, but must be viewed in relation to its cause (per comparationem ad suam causam). Aquinas uses this phrasing in the Summa theologiae in order to distinguish the act from the various contexts on account of which it occurred. For Aquinas, the blamelessness of nocturnal pollution in itself derived from the mental state of the sleeper, in particular his inability to use free will and thus to sin. Instead, if there is any fault, it lies with the earlier waking state which laid the foundations for the pollution. Aquinas states definitively, 'Thus it is clear that a nocturnal pollution is never a sin, but sometimes is the result [sequela] of an earlier sin', a statement which follows from Pseudo-Gregory's argument. ${ }^{58}$ Because Gratian had incorporated Pseudo-Gregory's letter into the Decretum, canon lawyers also devoted a considerable amount of space to the issue in the later twelfth and early thirteenth centuries. ${ }^{59}$

While the general theological consensus was that the sleeper could not sin, there are references to certain figures who apparently argued the opposite: that the sleeper could be held morally accountable for actions committed while asleep. Glossing Gratian's Decretum, the Summa Animal est substantia explicitly distinguished two groups: those who said nocturnal polluters had sinned while awake and those who said they sin while asleep. ${ }^{60}$ The advocates of the latter point of view are never named, and may simply be fictional contrarians

\footnotetext{
${ }^{58}$ Aquinas, ST 2-2, q.154, a.5, conclusio: 'Sic igitur patet quod nocturna pollutio nunquam est peccatum, quandoque tamen est sequela peccati praecedentis.'

${ }^{59}$ See James A. Brundage, 'Obscene and Lascivious: Behavioral Obscenity in Canon Law', in Obscenity: Social Control and Artistic Creation in the European Middle Ages, ed. Jan M. Ziolkowski (Leiden: Brill, 1998), 24659.

${ }^{60}$ Summa Animal est substantia, dist. 6, c. 3; 97-8, glossing the phrase veris imaginibus.
} 
created in order to fulfil the needs of scholastic dialectic. Nevertheless, the arguments made elsewhere in support of the thesis that the sleeper could sin contain rich materials about the sleeper's mental state. Thomas of Chobham remains largely neutral on the issue in his Summa confessorum: he begins by invoking the argument that sin must be voluntary but the sleeper does not have use of any will (voluntas), and thus there is no sin, either in the sleeper or in the act of polluting. But as a counter-argument he invokes a quote from the Song of Songs (5.2: 'I sleep but my heart is awake') and a verse from the hymn Jesu salvator seculi ('Our flesh sleeps so that the mind may stay awake in Christ'), which suggest to him that the sleeper has a greater agency and will than had been supposed. Thomas seems unable to resolve these arguments and in the end he sides with the second argument and simply states that nocturnal pollution is a sin, then refers the reader to Pseudo-Gregory. ${ }^{61}$ Both quotations revolve around a stark contrast between waking and sleeping selves existing simultaneously in the same person. It is not clear if the 'heart' and 'mind' of the Bible and hymn are simply alternative ways of talking about the soul; whatever their meaning, to Thomas of Chobham they leave open the possibility that some part of the person could remain vigilant during sleep, and thus could suggest some responsibility for actions in sleep.

Implicit in the moral discussions is a view of the sleeping person as radically different from his waking self. Because the sleeper could neither merit nor demerit, i.e. could perform neither virtuous nor sinful acts, he was not liable for any nocturnal emission he might produce. His agency and, in a sense, his personhood have been altered due to the inability to choose to do anything moral or immoral. At times, the sleeper was portrayed as less than fully human, parallel to a number of irrational beings, including the madman and animals. Awareness of the mental incapacities of the sleeper often led to a number of analogies

\footnotetext{
${ }^{61}$ Thomas of Chobham, Summa confessorum, 332 (1.2a.4): 'Sed contra in Canticis: ego dormio et cor meum vigilat. Et iterum in hymno: Sic caro nostra dormiat / ut mens in Christo vigilet... Istam questionem non oportet hic determinare.' Sed semper credatur Gregorio et dicatur quod illusio nocturna est peccatum.'
} 
between various states of mind which differed from the normative waking state. Comparisons between the sleeper and the child, the drunk, the idiot and the mad were commonplace in a variety of medieval literatures. Each of these had an impairment of his or her ability to think rationally, although in the case of the sleeper that irrationality was an only temporary (albeit recurring) state. In terms of moral consequences, the madman and sleeper shared an impairment of the intellect which called into question their ability to choose freely between right and wrong actions, and as a result, both were generally considered to have no responsibility for their actions. Aquinas, for example, invokes the view that the sleeper - like the madman while he is insane - incurs no blame for actions occurring while asleep. ${ }^{62}$ However, contrary to this general claim, there existed an argument that a person who had made himself mad (that is, whose wilful actions while sane had brought about his insanity) could be held accountable for actions he performed while mad. This enabled an analogy between the madman whose actions had caused his madness and the nocturnal polluter whose previous actions had led to the emission. While the analogy is not entirely successful, in both cases the interplay between past (rational) and present (non-rational) actions is essential: an earlier fault (culpa precedens) could give new and darker meaning to actions performed during a state - sleep or madness - which should be blameless. While the notion of culpa precedens would be undermined and removed from discussions of the mad during the thirteenth century, ${ }^{63}$ it continued to be relevant in discussions of the sleeper, in part because it underlay Pseudo-Gregory's arguments for the sinfulness of two forms of nocturnal pollution - to wit: those caused by excessive food or drink, resulting in a venial sin, and those caused by earlier lustful thoughts, resulting in a mortal sin.

\footnotetext{
${ }^{62}$ Aquinas, ST 2-2, q.154, a.5, conclusio.

${ }^{63}$ Brandon T. Parlopiano, 'Madmen and Lawyers: The Development and Practice of the Jurisprudence of Insanity in the Middle Ages' (Ph.D. diss., Catholic University of America, 2013), 199-222. Thomas of Chobham invokes the culpa precedens argument, Summa confessorum, 332 (1.2a.4), and cites Pseudo-Gregory as an authority.
} 
But theologians and canon lawyers did not simply invoke comparisons with the mad in order to explain the sleeper's cognitive incapacities. The Summa Animal est substantia identifies an analogy which moves beyond the human:

In sleep the body sins but the soul does not; thus the sleeper sins like the irrational animal (quasi brutum animal). But nothing [sinful] is imputed to the animal, and so neither is it imputed to the sleeper. The flesh is the handmaiden of the soul, so that when the flesh does something without the soul's knowledge (anima nesciente), it must not be imputed to the soul. ${ }^{64}$

Although the sleeper's irrationality is only temporary, unlike that of the animal, both sleeper and beast nonetheless share a common inability to sin which stands in contrast to the waking person's status. Another manuscript of the same Summa briefly notes that in sleep 'one's reason is drunk', a reference to another type of person, the drunkard, who was considered, like the sleeper, to be temporarily non-rational. ${ }^{65}$

\section{Reinterpreting the physical as mental}

The focus on desire, both that of the waking person and the sleeper, allowed for a shift in the theological and canon law materials away from the physical and toward the mental state of the sleeping polluter. This is perhaps best witnessed in the medieval interpretations of the central biblical passage relating to nocturnal pollution, Deuteronomy $23.10-11 .^{66}$ The original Mosaic law had focused on the somatic aspects of nocturnal emissions: the uncleanness of the body due to the pollution; the physical removal of the polluter from the

\footnotetext{
${ }^{64}$ Summa Animal est substantia, 102 (dist 6, c. 1): 'quia in sompno corpus peccat et non anima. Unde homo tunc peccat quasi brutum animal, set bruto animali non imputatur aliquid, ergo nec dormienti. Caro enim est ancilla anime. Unde cum caro facit aliquid anima nesciente, non debet imputari anime.' This Summa includes immensely rich material on nocturnal pollutions.

${ }^{65}$ Summa Animal est substantia, 104 (dist 6, c. 1): 'per sompnum. Bene dicit quasi, quia ex quo vigilat non potest se excusare per sompnum, set sompnum, quia inebriatur eius ratio, ex quo consentit peccato.'

${ }^{66}$ Sometimes interpreters credit the passage to Leviticus and even Exodus (Summa Animal est substantia, 101 dist. 6 , c. 1 .
} 
social space of the believers; and the reintegration of the polluter into the camp after a cleansing and purification of the body at sunset. Christian interpretations of the Old Law often downplayed the literal and corporeal aspects of Jewish law and transformed them into more spiritual concerns, as seen famously in Paul's contrast of a Jewish physical circumcision of the flesh and a Christian spiritual circumcision of the heart (an internal, heartfelt conversion, Romans 2:29). The spiritual interpretation of the law, as noted by the author of the Summa Animal est substantia, was a reminder that 'spiritual things have been promised to Christians, while earthly things were promised to the Jews. ${ }^{96}$

In relation to nocturnal pollutions, the spiritual sense downplayed bodily in favour of mental contamination. In discussing the passage from Deuteronomy, Huguccio glosses the term 'uncleanness' as 'unclean thought', transforming the believer's physical state into a cognitive one ${ }^{68}$ It seems the emission of seed was simply a less important consequence of the desire in the mind: in a passage we have already encountered, Pseudo-Gregory had noted that 'tempted to uncleanness, [the polluter] is defiled in his thoughts by true images.' ${ }^{69}$ The Glossa ordinaria on the Decretum comments on this passage by all but erasing the corporeal from the discussion when mentioning 'one who is polluted by depraved thoughts in his mind' with no direct reference to seminal emission. ${ }^{70}$ Pollution here has become first and foremost a mental phenomenon. The state of the mind takes precedence over that of the body, not simply because the mind's defilement occurs first but also because it is considered the more problematic impurity.

\footnotetext{
${ }^{67}$ Summa Animal est substantia, 97; dist. 6, c. 1; Rufinus, Summa decretorum, 19: 'Christianis spiritualia sunt promissa, iudeis autem terrena.'

${ }^{68}$ Huguccio, Summa decretorum, 107 (dist 6, c. 1): 'immunditia: id est immunda cogitatione.' The passage later appears in the Glossa ordinaria on the Decretum; see Decretum Gratiani emendatum et notationibus illustratum vna cum glossis (Rome: In aedibus populi Romani, 1582), 22 and the Summa Animal est substantia, 104; dist. 6, c. 1 .

${ }^{69}$ Bede, EH 1.27; Gratian, Decretum, dist. 6, c. 1-3: 'tentatus immunditia veris imaginibus in cogitatione inquinatur.' This is the passage from which the phrase 'true images' (discussed above) derives.

${ }^{70}$ Glossa ordinaria on the Decretum, 22: 'de illo qui in mente prauis cogitationibus est pollutus.'
} 
By the thirteenth century, this reappraisal of the Mosaic Law on nocturnal pollution as a mental rather than physical delinquency allowed it to be reclassified under the category of sins of thought (peccata cogitationis). That is, the shift away from a physical misdeed and toward one based primarily in the mind can be seen as part of a larger shift from the twelfth century onward of looking at intentionality and internal contexts for sinful acts rather than the actions themselves. ${ }^{71}$ Here, however, the language suggests that the act itself is irrelevant, as it is only a sign or by-product of a sin of thought. Nocturnal pollution, in this sense, appears in an anomalous situation in which a physical act qualifies as a mental sin, or at least a sign or consequence thereof. This was further complicated by the role of earlier waking thoughts and the temporal dimensions of the sin. We have already encountered the notion of a lingering thought or desire in the context of creating a fixed image in the waking mind, which would then be transferred to the sleeping mind. This prolonged fixation also held a moral implication, and occasionally suggested an increased culpability based on the quantity of time expended in thinking about the object of lust. On a practical level, Peter of Poitiers in his confessor's manual of the early thirteenth century emphasises the idea that this mental dawdling (mora) can itself compound the sin depending upon the amount of time spent in lingering over the thought and whether or not the individual accepted or rejected the 'illicit thought'. ${ }^{72}$

Free will and the incapacities of sleep

\footnotetext{
${ }^{71}$ On twelfth-century interest in the sinner's intentions, see Peter King, 'Abelard's Intentionalist Ethics', Modern Schoolman 72 (1995): 213-31. For the thirteenth-century distinction of sins of deed versus sins of thought, see Alexander of Hales, Summa theologica (Florence: Quaracchi, 1924-48 [1930]), lib. 2, inq. 3, tract 3, vol. 3, 357-61, and Aquinas, ST 1-2, q.72, a.7.

${ }^{72}$ Peter of Poitiers, Summa de confessione, 18 (c. 13): 'Moram illam periculosam si amplius uolendo et delectando moratur quis, nec repellit pro posse cogitationem illicitam et quae tendi ad illicitum, iam est ibi quidam consensus morae et delectationis.'
} 
The argument that a nocturnal pollution arising from lustful thoughts and images was a mortal sin received a number of refinements, including attempts to explain nocturnal pollution as a process centred on the mind. Canon lawyers, for example, dissected the possible responses to the erotic images appearing in the sleeper's mind by distinguishing between at least four things: the (seemingly passive) production of the image itself, the lust or sexual excitement which was engendered by the image, the subsequent ejaculation and finally the pleasure obtained from the act. The canon law materials downplayed the bodily mechanics of the pollution and instead focused on the mental contexts in which it needed to be understood. One version of the Summa Animal est substantia notes the complexities of the situation:

If [the pollution arises] out of a preceding thought, it should be distinguished: if it proceeded from that thought to consent and the man delighted in the thought, then the thought will be a mortal sin and the consequent pollution as well, and thus he commits two mortal sins. ${ }^{73}$

The division between desire, pleasure and consent appears in theological as well as canon law sources, although there was some resistance to this taxonomy. Aquinas queried the division by noting that it could be difficult to distinguish between the three elements; the thought or desire is closely linked to delight, which equally can blur with consent, creating a conundrum which must be carefully disentangled. ${ }^{74}$

The discussion of nocturnal pollution's moral consequences often centered on a binary opposition between the waking and sleeping states, parallel to that invoked in Aristotle's De somno. But in contrast to Aristotle's interest in the physical incapacities of

\footnotetext{
${ }^{73}$ Summa Animal est substantia, 96; dist. 6, c. 1: 'Si ex precedenti cogitatione: distinguitur; quod si processit ex illa cogitatione ad consensum et delectatus est homo in cogitatione, tunc cogitatio fuerit mortale peccatum et sequens pollutio similiter; et ita committit duo mortalia.'

74 Aquinas, Super Sent. lib. 4, d.9, q.1, a.4, q.2, conclusio; vol. 4, pp. 388-9. See also Aquinas, ST 3, q.80, a.7, conclusio.
} 
sleep, theologians and canon lawyers unsurprisingly more often focused on the intellectual and moral absences of sleep. The brain's inability to function to its fullest extent during sleep raised considerable moral concern. One formulation by Pseudo-Gregory pinpointed the problem and was cited frequently: 'what the knowing one thought, the ignorant/unknowing one carried out' ('quod cogitavit sciens, hoc pertulit nesciens'). On one level, in identifying the waking person as knowing, sciens, and the sleeper as ignorant, nesciens, this passage referred to the general lack of awareness in sleep; the sleeper is sometimes ignorant of the physical actions his body is performing while asleep. In this interpretation, like some sort of automaton, the sleeper unknowingly enacts or fulfils a sexual desire of the waking state. The sleeper's status as blissfully unaware is a negative definition (his inability to know) with a morally neutral outcome: Simon of Bisignano notes that 'at that time [i.e. while asleep] one is unknowing, and there is no sin for unknowing ones. ${ }^{75}$ For the compilers of the Glossa ordinaria on the Decretum, Pseudo-Gregory's use of the verb 'to carry out' (pertulisse) in this instance should be understood as 'to endure passively (pati) rather than to do (facere)', highlighting the sleeper's lack of agency and, in this context, lack of knowledge and consent. This distinction between the individual as, at one moment (while awake), having knowledge and, at another (while asleep), being ignorant has a very important moral significance: knowledge in this instance refers primarily to the ability to exercise free will. While awake, it was argued, we know what we do, in the sense of having volition as well as knowledge of an action's consequences, but while asleep we do not have proper knowledge to distinguish between right and wrong. The contrast between having knowledge and being ignorant (sciens versus nesciens) finds a direct parallel in another opposition between those who have free will and those who do not (volens versus nolens). Master Honorius in his Summa on the

\footnotetext{
${ }^{75}$ Simon of Bisignano, Summa in Decretum, ed. Petrus V. Aimone (Vatican City: Biblioteca apostolica vaticana, 2014): 'tunc homo sit nesciens et peccatum nescientium nullum est.' See also Huguccio, Summa decretorum, 111 (dist 6, cap 1, gloss on pertulit nesciens, on the sleeper's ignorance in completing the act).
} 
Decretum notes that 'while asleep we do not will anything' and consequently 'we were deceived without willing it and thus we do it [have a pollution] without willing it.' ${ }^{76}$ In the waking state, the combination of voluntas and voluptas, free will and sexual pleasure, would lead to a mortal sin, but the sleeper's mental and moral deficiencies complicate matters considerably. The sleeper's inability to consent to the desire and pleasure he feels in sleep places the act of sexual climax in an ambiguous position. After citing Pseudo-Gregory's letter, Gratian included in the Decretum a quote from Isidore of Seville which left the moral status of nocturnal emissions open: if the sleeper experienced erotic images and polluted himself but did not have desire, then there was no blame. But Huguccio glossed the phrase 'not desiring' (non concupiscendo), as 'without any consent to lust in earlier thoughts', thereby shifting the emphasis from desire to consent. ${ }^{77}$ The general consensus that the sleeper was capable of sexual desire was mollified by the argument that, without full use of free will and the ability to consent, the act of self-pollution in sleep was not in itself sinful.

In an important sense, the discussion of voluntary action occasionally fuses the moral and natural philosophical discourses on the sleeper's abilities or, more precisely, incapacities. The theological claim that free will is bound in sleep found a corollary in the naturalphilosophical argument that the brain's deliberative faculty is also not functioning. In both instances sleep becomes a state of incapacity and constriction, with the added complication that morally the consequences could be dangerous to the soul. The concerns over the sleeper and sin elicited several contradictory observations: although the sleeper may not be liable for sin, his mind could create immoral scenarios precisely because the rational faculty was not present to resist them. Pseudo-Gregory's letter quotes from Paul's letter to the Romans 7.23:

\footnotetext{
${ }^{76}$ Rudolf Weigand, Peter Landau and Waltraud Kozur, eds., Magistri Honorii Summa 'De iure canonico tractaturus' (Vatican: Biblioteca Apostolica Vaticana, 2004), 22: 'Non est nolentes: Ita hoc dicit ac si nolentes luderemur, cum dormientes nichil uolumus. Resp: nolentes illudimur tum nolentes id agimur.'

${ }^{77}$ Huguccio, Summa decretorum, 114; dist. 6, c. 3: 'non concupiscendo: id est sine consensu ad concupiscentiam in precedenti cogitatione.'
} 
'but I see in my members another law waging war against the law of my mind and making me captive to the law of sin which dwells in my members. ${ }^{78}$ Paul envisions a conflict of body and mind (or soul) in which the base desires associated with the genitals overwhelm the desire to be morally upright, associated here with the mind. In the context of nocturnal pollutions, the sleeper's mind has fallen victim to the law of sin and seems to be compelled to follow bodily desires. The compulsion to enact, mentally and physically, one's waking desires is a result of the sleeper's complete lack of control over his mental processes. The twelfth-century Cistercian treatise De spiritu et anima, mentioned earlier in reference to the realness of dreams, gives a sense of the powerlessness of the sleeper's mind. We are told that, while awake, chaste people have the ability to resist temptations, 'but sleepers cannot, because they do not have power over the expression of bodily images'. ${ }^{79}$ The sleeper cannot control the images which appear in his mind, and thus cannot control the bodily movements which respond to those images.

\section{Morally neutral erotic dreams}

Some of the sources imply that any appearance of erotic images in the imagination constituted evidence of a prior lust and was thus indicative of a mortal sin. The future Pope Innocent III, Lothario de Segni, had noted that such mental images always 'not only pollute the body but stain the soul' ${ }^{80}$ But increasingly from the later twelfth century, theologians and canon lawyers identified a variety of instances in which erotic images could appear in the mind without culpability. Aquinas noted that even a sinless pollution arising naturally could

\footnotetext{
${ }^{78}$ Romans 7.23, Biblia sacra iuxta vulgatam versionem, ed. Webb, vol. 2, p. 1758: 'video autem aliam legem in membris meis repugnantem legi mentis meae et captivantem me in lege peccati quae est in membris meis.'

${ }^{79}$ De spiritu et anima, PL 40, col. 796; McGinn, Three Treatises, 216: 'dormientes autem ideo non possunt, quia in potestate non habent imaginis corporalis expressionem.'

${ }^{80}$ Lotharii cardinalis (Innocentii III), De miseria humane conditionis, ed. Maccarrone, 31-2 (1.24): 'per illusiones nocturnas non solum corpus polluitur, sed anima maculatur.'
} 
involve erotic imagery: sometimes in the sleeper who has nocturnal emissions due to an excess of humours, 'there are formed in the imagination phantasms relating to the emission of such superfluities. ${ }^{81}$ This is a rare instance within the religious writings on nocturnal pollution in which the body was thought directly to influence the mind: the body needs to remove a naturally-occurring superfluity of semen and thus causes the mind to produce images which would allow for the seed's successful removal. The need to balance the liquids in the body by expelling the superfluity brings about the erotic images, which as a result of their corporeal origins are not sinful.

Over the course of the thirteenth century, theologians in particular identified a variety of situations which qualified and refined the overly-simple argument that the appearance of erotic dream imagery inherently indicated a mortal sin. Thomas Aquinas and, following him, John of Freiburg argued for a hierarchy of imagination-based pollutions, rewriting and refocusing the hierarchy laid out in Pseudo-Gregory's letter. ${ }^{82}$ At the lowest, most blameworthy level lay those we have already encountered, who experienced erotic images because they had willingly lusted after a woman while awake. The middle level of Aquinas' hierarchy introduces greater subtlety to the discussion: Thomas imagines an individual whose thoughts of another person begin as affection but are transformed into lust without the polluter's consent or intention. Aquinas does not elaborate much on this middle level, but it seems that, because the person's original purpose in thinking of the other individual was not lustful or at least not wilfully so, moral responsibility for the pollution was diminished and the sin was only venial.

\footnotetext{
${ }^{81}$ Aquinas, ST 2-2, q.154, a.5, conclusio: 'quandoque formantur in imaginatione phantasmata pertinentia ad emissionem talium superfluitatum.'

${ }^{82}$ Aquinas, Super Sent, 'lib. 4, d.9, q.1, a.4, q.2, conclusio; vol. 4, p. 389; John of Freiburg, Summa confessorum (Lyons: Jacques Sacon for Johannes Koburger, 1518), f. 123va (3.24.73).
} 
In Aquinas' revised hierarchy of nocturnal pollution, the highest and least culpable category is reserved for those who have a nocturnal emission which arises from the imagination but is not at all considered sinful. One example appears most often in such discussions: the figure of the scholarly disputant. This involves someone who has been engaged in a scholastic debate about a sexually-themed topic and, purely as a result of talking about sexuality, later has a nocturnal pollution without any sexual desire or will. This might seem to be an oddly specific figure, but he has a long pedigree, going back at least to Augustine of Hippo who, in his De Genesi ad litteram, had invoked a parallel case of a preacher who innocently gives a sermon about sexuality. Both the disputant and the preacher have had sexual thoughts placed in their minds through no fault of their own (on the contrary, they were simply doing their religious duty), and later found that those thoughts reappeared in their dreams and unwillingly led to nocturnal pollutions. Augustine's discussion of nocturnal pollution, which circulated separately from the original text in the twelfth-century monastic world, makes it clear that the preacher's waking thoughts were blameless. Augustine is particularly sympathetic to this preacher and wryly observes that 'undoubtedly one must think about something in order to speak about it. ${ }^{83}$ Aquinas refers to 'earlier lascivious thoughts' occurring without sin due to lecturing (lectionis, perhaps just reading) or debating because the polluter had been compelled to think of such things. ${ }^{84}$ Similarly Aquinas claims that the debater experienced a 'purely speculative' form of erotic imagining and may

\footnotetext{
${ }^{83}$ Augustine, De Genesi ad litteram, 12.15 [31]; vol. 2, pp. 378-80: 'Porro ipsa phantasia, quae fit in cogitatione sermocinantis, cum ita expressa fuerit in uisione somnianti s... tam sine peccato fiat, quam sine peccato a uigilante dicitur.' A large-format bible from Waltham Abbey, dating to the late twelfth century and currently held by the Epping Forest District Museum, includes this quote from Augustine's De Genesi ad litteram, 12.15 [31] in an unusual location: at the beginning of the manuscript, immediately before the Book of Genesis, and after a contemporary catalogue of the abbey library's holdings. I thank Charles Burnett for pointing out the manuscript to me. The same text appears in the unedited text De laude liberi arbitrii, 3.9, by Frowinus, abbot of Engelberg (d. 1178); see Einsiedeln, Stiftsbibliothek, Cod 26, f. 120r.

${ }^{84}$ Aquinas, ST 3, q.80, a.7, conclusio: 'Similiter etiam praecedentes cogitationes lascivae quandoque possunt esse omnino sine peccato, puta cum aliquis causa lectionis vel disputationis cogitur de talibus cogitare.' I have translated lectionis as lecturing rather than reading, although that translation could equally apply. The same quote from Augustine appears in Super Sent. lib. 4, d.9, q.1, a.4, q.1, sed contra; vol. 4, p. 384, par. 133.
} 
even have expressed horror at the images; as a result he was not culpable because the preceding cause was blameless. ${ }^{85}$ In this instance of sinless pollution in sleep, the passive and morally ambiguous nature of the imagination is made clear: it is simply a receptacle of sense impressions, removed from any conscious intention of the individual and simply recreates the sensations and thoughts of the waking state. Augustine's preacher and Aquinas' debater demonstrate the power which the imagination exerts over the sleeper, against which he seems to be entirely powerless. They were unwilling participants, with apparently no desire before or during the pollution, and as a result Augustine and Aquinas absolve them of any wrongdoing. The body betrayed its own weaknesses, and apparently reacted with a lustless ejaculation to the erotic images in the mind.

\section{External attacks on the sleeping mind}

The idea of a sinless sexual desire and seminal emission occurring in sleep takes on a very different significance in the discussions of yet another cause of nocturnal emissions: the influence of the Devil. Our discussion has thus far focused primarily on causes arising from within the sleeper's mind or body, but theologians and canon lawyers recognised the possibility of a powerful external influence on the sleeper: the demonic. Yet even here the emphasis is more on the sleeper's cognitive processes than on the body. The Devil was thought to infiltrate the sleeper's mind, but the precise mechanism by which he did so was a source of controversy for some thinkers. Figures such as Huguccio expressed doubts over the specific details of this mental invasion: central to the discussion was whether the Devil introduced lustful thoughts or simply incited existing ones (non est immissor cogitationum set incentor). Did he infect the air, and thus somehow bring the woman back to the man's

\footnotetext{
${ }^{85}$ Aquinas, ST 2-2, q.154, a.5, sed contra: 'Cogitatio autem quae in vigilia praecessit, quandoque est pure speculativa, puta cum aliquis causa disputationis cogitat de peccatis carnalibus.'
} 
memory ${ }^{86}$ Pseudo-Gregory invokes a three-part process to explain how the Devil induces nocturnal pollution: suggestion, pleasure and consent. The Devil suggests things through thought (in some versions of the text, he sows the seed through thought), then the flesh is drawn in through pleasure and finally the soul consents to that pleasure. ${ }^{87}$ This tripartite model was taken up by Rupert of Deutz in the early twelfth century as an explanatory model for 'all sins of thought,' although Rupert removes any direct reference to the Devil from the discussion. ${ }^{88}$ For Rupert, the explanation of nocturnal sin as a process which moves from mind to body and finally to soul once again prioritises the cognitive.

Discussions of demonically-induced nocturnal pollutions often emphasised the sleeper's passivity, which was greater than what we have previously encountered: this was not simply a mind recollecting fragments of what the person had experienced while awake, but a mind being manipulated by an external agent which forced images on it. In a treatise on penitence attributed to William of Auvergne, the Devil places in the sleeper's mind erotic images which cause the individual to emit semen. ${ }^{89}$ Albert the Great notes that many people were deluded in sleep by demons via filthy visions and that this was 'greatly to be feared' because 'both good and bad angels have power over the imaginative virtue, which is the interior sense.' Albert argues that all angelic creatures interact with sleeping humans by leaving an impression on the imagination, just as the sense perceptions arising from the common sense become sense impressions in the imagination. ${ }^{90}$

Because of his unique passivity when experiencing a demonic illusion, the sleeper was not held accountable for the pollution, unless he was guilty of some negligence which

\footnotetext{
${ }^{86}$ Huguccio, Summa decretorum, 112; dist. 5, c. 2.

${ }^{87}$ Bede, EH 1.27; Gratian, Decretum, dist. 6, c. 1-3.

${ }^{88}$ Rupert of Deutz, De trinitate et operibus eius, ed. H. Haake. CCCM 22 (Turnhout: Brepols, 1971), pp. 1044-5 (In Deut. 1.23): 'Tribus enim modis omne peccatum cogitationis impletur.'

${ }^{89}$ William of Auvergne, Supplementum tractatus novi de poenitentia, in Guilielmi Alverni episcopus Parisiensis supplementum (London: Robertus Scott, 1674), col. 234a (chapter 20)

90 Albert, Summa theologiae, in Opera omnia, ed. Borgnet, 32: 293b (5, 1. 23): 'Ex hoc accipitur, quod tam bonus quam malus [angelus] habent potestatem super imaginativam partem, quae est sensus interior.'
} 
could have prevented the assault. Aquinas discusses such sins of negligence in relation to nocturnal pollution, and particularly cites the idea of not preparing fully to defend against the possibility of oneiric attacks by the Devil. For Aquinas, those preparing for sleep should recite the hymn Te lucis ante terminum, which includes the stanza 'Let dreams and the phantasms of the night withdraw far away, restrain our enemy, lest our bodies be polluted. ${ }^{91}$ The combination of demons and dreams raised fears over sleep as a site of a battle within the mind, played out via nocturnal pollutions.

Several thirteenth-century collectors of exempla addressed exactly this issue of a possible demonic origin for nocturnal pollutions. In the Bonum universale de apibus, his collection of moralising stories built around the world of insects, Thomas of Cantimpré tells the story of a monk who had a nocturnal pollution but had not yet confessed. In front of a large crowd inside the church, a demon appeared and mocked him loudly, asking how he enjoyed the pretty woman whom the demon had brought to him the previous night. Although he seems to question the tale by labelling it 'ridiculous' (ridiculosum), Thomas nonetheless makes it clear that he believes the basic premise of the story: that nocturnal pollutions can arise from the influence of demons, who swarm around the sleeper at night like moths. Thomas notes that the demons 'pollute and delude [sleepers] with phantastical visions' ${ }^{92}$ Here again the pollution is primarily cognitive, the infiltration of the sleeper's mind and the implanting of false images of lust, and only secondarily the physical pollution itself.

A fragment connected to Caesarius of Heisterbach's Dialogue of Miracles tells the same story, which the author claims to have heard from the victim, whom he names as Marold, a monk from Eberbach. In this version, the demon speaks through a female

\footnotetext{
91 'Procul recedant somnia / et noctium phantasmata. / Hostemque nostrum comprime / ne polluantur corpora.' On sins of negligence in relation to nocturnal emissions, see Aquinas, ST 2-2, q.154, a.5.

92 Thomas of Cantimpré, Bonum universale de apibus (Douai: Ex typographica Baltazaris Belleri, 1627), 540 (2.57.5): 'nocte hominibus apparent in somnis, et eos visionibus phantasmaticis polluunt et illudunt.'
} 
demoniac who publicly announces the unconfessed nocturnal emission. The tales provide evidence not only of the Devil's influence in such matters, but also of the perceived realness of the apparition: the sleeper's mind has been fooled, this time by an external source, into thinking that he truly lay with a beautiful woman. For Caesarius, this is evidence of the Devil's power over human minds: the focus is on 'filthy imaginations, which we often endure in our dreams and which are sometimes brought on by the Devil, who does not even allow sleepers to rest' ${ }^{93}$ The writers of exempla invoke the same language of imagination, phantasms and filth which we have seen elsewhere in other genres, but they do so only in reference to an external demonic causality which appears comparatively infrequently in the theological, canon legal and certainly medical and natural philosophical literature. ${ }^{94}$

In all of these instances, the moral implications of a nocturnal pollution were inextricably linked to the cognitive context in which it occurred. Although the sleeper could not sin per se, his actions could only be understood and evaluated morally by identifying the earlier mental state of the individual. Even in the case of demonic attack, an insufficient amount of preparation of mind and soul at bedtime could transform an otherwise morally neutral pollution into one requiring penance. Nocturnal pollution in this sense involved a retrospective interaction of the sleeping with the earlier waking mind. But this was not the only interaction between sleep and waking which proved to be problematic; the relation between sleeping and re-awakening also brought its own dangers, as we shall now see.

\section{Afterthoughts: temporality, waking and consent}

\footnotetext{
${ }^{93}$ Caesarius, Die Fragmente der Libri VIII Miraculorum des Caesarius von Heisterbach, ed. Aloys Meister (Rome: In Commission der Herder'schen Verlagshandlung zu Freiburg im Breisgau und der Buchhandlung Spithöver zu Rom, 1901), 38 (1.25): 'turpes imaginationes, quas saepe per somnia patimur, quandoque fieri procurante diabolo, qui etiam dormientes quiescere non sinit.'

${ }_{94}$ Caesarius of Heisterbach, Dialogus miraculorum, ed. Joseph Strange. 2 vols. (Cologne: J.M. Heberle, 1851), 2: 83 (8.4).
} 
Two interrelated themes have played an important and recurring role in the discussion of nocturnal pollution: temporality and recollection. The most common explanation for nocturnal pollution involved the interplay between past and present, between earlier waking sense perceptions, their entry into the imagination as sense impressions and their later return to the sleeper's mind. The relation between temporalities was complex, since the individual's past sense perceptions became the sleeper's present, recreated as if they were occurring at that moment, although entirely imaginary. We have also seen the connections between temporality and recollection in the notion that these images could reappear in sleep precisely because the person's waking thoughts lingered over the object of desire. The moral concern over nocturnal emissions emphasised the importance of the individual's past thoughts and actions as the most essential contextual information in identifying whether or not the pollution was sinful. All of these involved a movement between an earlier waking past and a later sleeping state which responded to earlier sensations.

But sources of the later twelfth and early thirteenth centuries complicated matters further by turning toward the other end of the sleep cycle, in particular the interplay between the sleeping state and the return to waking in the morning. In the decades around the year 1200 , the transition from sleeping to waking became an object of inquiry to theologians and canon lawyers, in ways which identified new dangers associated with sleep and the periods surrounding it. Theologians and canon lawyers identified new anxieties over nocturnal pollutions and, in doing so, problematised the very definition and moral implications of waking up. The closer scrutiny of the transition from sleeping back to waking once again particularly focused on the mind, specifically the relation between the workings of the sleeper's imagination and waking memories.

Central to the discussion was the question: When was the individual properly awake? In the religious literature of the twelfth and thirteenth centuries, discussions of nocturnal 
pollution revolved largely around the relation between thought and sensation, a connection summed up in the multiple meanings of the words associated with the verb sentio. Huguccio and Aquinas used the phrase 'to come to one's senses' (redit or reducatur ad sensum; note the use of both active and passive verbs) in reference to the individual awakening from sleep. ${ }^{95}$ The phrase often takes on a meaning parallel to the modern usage of the phrase, with its implication of a return to normative cognitive as well as sensory functioning. This would entail the ability to receive external sensations and, more importantly for our purposes, the ability to think rationally and deliberatively and to consent to sin carnally. In this way, sentire and consentire - to sense or think clearly and to consent - were closely bound together.

The concern over the boundaries between sleeping and waking can be found in discussions of a particular scenario: when a person begins to have a nocturnal pollution, but wakes up in the midst of it. Because this emission of seed bridged the gap between the two states, it caused concerns over how to define the individual's culpability: a 'pollution which begins in sleep and ends in the waking state' could mean that it would immediately be considered a mortal sin. But this was not the case. Aquinas answered the question in the negative, with the following explanation: because it began in sleep, a state during which one cannot choose between right and wrong, it follows that the pollution is not a sin.

Bodily movements do not pertain to merit or demerit unless they are caused by the will; if a movement of the flesh is aroused in sleep, the later movement [i.e. the completion of the movement, ejaculation] is not subordinate to the will of the person who has awoken, nor is he reputed to have awakened until he has fully recovered the use of free will. ${ }^{96}$

\footnotetext{
${ }^{95}$ Huguccio, Summa decretorum, 104; dist. 6; Aquinas, Super Sent. lib. 4, d.9, q.1, a.4, q.1, conclusio; vol. 4, pp. 386-7.

${ }^{96}$ Aquinas, Super Sent. lib. 4, d.9, q. 1, a.4, q.1, ad 1; vol. 4, p. 387, par. 149: 'corporales motus non pertinent ad meritum vel demeritum, nisi secundum quod a voluntate quasi a principio causantur; et ideo nocturna pollutio magis judicatur quantum ad rationem meriti vel demeriti, secundum principium quod est in dormiendo, quam
} 
There is nothing new in the first argument, about sleep and its lack of free will. However, the final sections of the passage contain some very important and novel observations about the process of awakening and its moral implications. Seemingly ignoring any earlier mental causes, Aquinas (and John of Freiburg, who again closely follows the Angelic Doctor) focuses on the physical activity of ejaculation, ${ }^{97}$ which, because it is in its origins detached from volition due to the sleeper's status, cannot be the cause of demerit in the individual who has just awakened. The waker simply completes the movements begun in sleep, and receives no blame for it. However, the final phrase of the quotation shifts the argument in a different direction: for Aquinas, the transition from waking to sleeping does not occur in a single moment, but is a process, defined not in terms of opening one's eyes and moving, but in terms of the ability to reclaim one's free will. Aquinas seems to imply that the waker is not fully awake, cognitively and volitionally. Aquinas is questioning what it means to be truly, morally and intellectually awake and what we now call the hypnopompic, the transitional period between sleeping and awakening.

A century earlier, canon lawyers had discussed a parallel scenario but from a different angle: they imagined a husband who has been dreaming of his wife and woke up midpollution. For Huguccio, one of the first to discuss the scenario, the question revolves around the moral status of this individual, who upon returning to his senses (redeat ad sensum) finds pleasure in the pollution and consents to it. Because the man's night-time fantasy was fixated on desire for his wife, it involved a morally correct object of desire, rather than the fornication implicit or explicit in the more general discussions of nocturnal pollution. The

secundum terminum qui est in vigilando: quia ex quo in dormiendo excitatus est motus carnis, non subjacet voluntati vigilantis ulterius motus ille, nec reputatur evigilasse, quousque perfectum usum liberi arbitrii recuperavit.' Repeated in John of Freiburg, Summa confessorum, f. 123vb (3.24.74, De sacramento eucharistie). ${ }^{97}$ It is worth emphasising that Aquinas here does not address the issue to which he and many others devoted a large amount of time and thought: the mental and moral causes of the pollution itself, in particular, the issues we have been discussing about the remnants of prior thoughts and emotions. 
moral culpability concerns the man's pleasure and consent, the latter of which could only have been given while awake, and it is due to these aspects that the pollution would normally qualify as a mortal sin. This instance is still a sin, because it is an explicitly sexual dream, a product of the imagination and waking desire, but the husband's culpability is diminished because he could not fully distinguish the dream from reality. ${ }^{98}$ Because it was a (misplaced) attempt to fulfil the conjugal debt, the moral value of the sin was reduced from mortal to simply venial.

Central to this discussion was the question of what constitutes the waking state, the answer to which was not quite as straightforward as it might seem. Several writers argued that the very act of desiring, as well as the act of ejaculating, produced a dullness or heaviness of mind (hebetudo mentis), which would affect the individual during and after the pollution. ${ }^{99}$ Lust and its fulfilment were seen as analogous to sleep: 'in fornication, one is made sluggish and succumbs, and is as if slumbering. ${ }^{\prime 00}$ The fog of desire creates a dullness of mind and the individual succumbs to lust and gets lost in a sleep-like oblivion from which it is difficult to be freed, thereby making it even more difficult to awaken after a nocturnal emission.

The issue of consenting to sin raised a number of issues concerning the relation between sleeping and awakening. This can be seen in one further scenario which appeared in several theological compendia of the second half of the thirteenth century: the question of whether or not it is possible to lose one's virginity through a nocturnal pollution. John of Freiburg devotes a whole questio to the topic in his Summa confessorum, and cites Aquinas

\footnotetext{
${ }^{98}$ Huguccio, Summa decretorum, 104-5; dist. 6. The Glossa ordinaria on the Decretum acknowledges Huguccio's argument, but disagrees with it (21).

99 Aquinas discusses the idea extensively in Super Sent. lib. 4, d.9, q.1, a.4, q2, conclusio; vol. 4, pp. 388-9 and John of Freiburg copies the passage, Summa confessorum, f. 132rb (3.24.73).

${ }^{100}$ Summa Animal est substantia, 101; dist. 6, c. 1: 'in fornicatione inde hebetatur et succumbit, et est quasi sopita.'
} 
and Ulrich of Strasbourg as his sources. ${ }^{101}$ He concluded that generally, but with important exceptions, a nocturnal pollution did not remove virginity. Aquinas argued that there were three requirements for virginity: a formal element, that is, the choice (electio) or intention of the will; a material aspect, which consists of 'the passion of the sensitive appetite, that is, the pleasure of the venereal act'; and an accidental (per accidens) component, bodily integrity. ${ }^{102}$ This list created a hierarchy moving downward from volition to sensation and, only at the end, to the purely anatomical. The definition could be applied to both men and women, although the final category generally referred to the integrity of the hymen. The recognition of multiple types of virginity appeared in discussions of nocturnal pollution; the Parisian theologian Guerric of Saint-Quentin, writing in the 1240s, notes that, if a virgin has a pollution at night and a demon mixes male semen with it to impregnate her, she will remain a virgin in mind and in body. ${ }^{103}$ The discussion of virginity is the only moment in the religious literature which alludes to the possibility that women could have nocturnal emissions. The medical and natural-philosophical traditions had posited, through the Hippocratic-Galenic two-seed model of generation, that both men and women produced and released semen, a model which allowed for the possibility of women's nocturnal emissions. ${ }^{104}$ At the end of the thirteenth century, John of Freiburg argued that a virgin who experienced nocturnal pollutions would retain his or her virginity unless it arose from earlier desires and 'the

\footnotetext{
${ }^{101}$ John of Freiburg, Summa confessorum, f. 98vb (3.3.22: Utrum per pollutionem in somnis amittatur virginitas).

102 Aquinas, Quaestiones de quodlibet, Cura et studio fratrum praedicatorum, in Sancti Thomae de Aquino Opera omnia, vol. 25 (Rome: Commissio Leonina, 1996), 312-13 (6.10.2): "passio appetitus sensitivi, scilicet delectatio quam quis experitur in actu venereo.'

${ }^{103}$ Guerric of Saint-Quentin, Quaestiones de quolibet, eds. Walter H. Principe and Jonathan Black (Toronto: Pontifical Institute of Mediaeval Studies, 2002), 264 (2.44): 'Item, esto quod virgo polluatur dormiendo et diabolus immittat semen virile. Illa remanet virgo mente quia non peccavit, et corpore quia clausum est signaculum.'

${ }^{104}$ Natural-philosophical sources discussed female nocturnal pollutions in greater detail, but in reference to purely physical rather than cognitive and moral concerns. See, e.g., Albert, De animalibus 9.1, Opera omnia, ed. Borgnet, 11: p. 483a.
} 
pleasure satisfied [him or her] either before or after. ${ }^{105}$ In this moral and mental definition of virginity, what mattered was not simply the sensation of pleasure but whether or not the individual consented to that sensation. What is most striking is the focus on two temporal moments, the periods before and after the pollution. The argument for culpability due to prior pleasure and consent was well established, as we have seen, but the reference to pleasure and consent after the fact, upon awakening, seems to be a largely thirteenth-century addition and had a much wider application than simply the retention of virginity.

The argument that the period after sleep could retrospectively problematise what the sleeper experienced revolved once again around the issue of free will. The terminology often used by theologians and canon lawyers contrasted the idea of sleep as binding and waking as liberating. The mind, like the body, was thought to be bound or held captive in sleep; for Rufinus, commenting on Gratian's Decretum, 'the mind is not free, when the man, while sleeping, is polluted; ... it is not free in its judgement.' ${ }^{106}$ The mind was equally bound by the phantasms produced in the imagination out of the remnants of earlier perceptions.

Paradoxically, the sleeper was free of sin precisely because his will was bound in the sleeping state. But what happened when the mind was loosened of its bonds? The liberation of the waking mind was also a liberation of the will, and again paradoxically entailed the freedom to choose to be bound by sin. Huguccio refers to waking as being 'released from sleep and existing', a rather mysterious phrasing which a later Summa rewrites as 'existing with the liberty of judgement, that is, after waking' ${ }^{107}$ If sleep was a freedom from sin, then waking was a freedom of the will which included the possibility of enslavement to sin.

\footnotetext{
105 John of Freiburg, Summa confessorum, f. 98vb (3.3.22): 'Quod enim placeat delectatio pollutionis nocturne ante vel post.'

${ }^{106}$ Rufinus, Summa decretorum, 19. See also Weigand, Landau and Kozur, eds., Summa 'Omnis qui iuste iudicat' sive Lipsiensis, 1: 24: 'mens non est libera tunc, cum dormiendo homo polluitur; non est libera, inquam, sic ut prohibere valeat; non est libera, dico, vel - i.e. saltem - suo iudicio,'

${ }^{107}$ Huguccio, Summa decretorum, 110; dist. 6, c. 1, and Summa Animal est substantia, 99; dist. 6, c. 1: 'Libera. Idest soluta a sompno et existens cum libertate iudicii, scilicet post evigilationem.'
} 
Sleep was generally seen as a morally neutral state but the waking states on either side of it - both before and after the person rests - were periods of danger which could be affected by the mental and physical actions of the sleeper. In the early thirteenth century, there arose an argument that, just as a nocturnal emission could compound a sin of the previous waking state, so it could also lead the person, once awake, into mortal sin. Albert the Great mentions that several earlier theologians ('certain ancient masters') had argued, among other things, for culpability after the fact:

And they say that the pollution is not a sin except out of the consent which after sleep is fulfilled in the waking person, and according to the quantity of that consent he takes a quantity of sin. They say also that such pollution has its beginning in sleep and is completed by consent upon awakening. ${ }^{108}$ The argument parallels Pseudo-Gregory's statement about the sleeper fulfilling what was begun in the waking state, but inverts it: the waking person finds pleasure in the prior actions, real and imagined, of the sleeping state. The connection between the processes of waking and desiring can be seen in the use of the verb excito, which implied both arousal from sleep and sexual arousal. The advocates of this argument, Albert tells us, defended their views with the claim that we should not remember past misdeeds with pleasure but with sorrow and sadness. Bonaventure makes a similar argument when, after acknowledging that the sleeper can neither merit nor demerit in sleep, he notes that, once we awaken, we are able to commit sin: 'by remembering it afterwards, he finds pleasure' and thus sins mortally. ${ }^{109}$ The Summa

\footnotetext{
108 Albert, Summa theologiae, in Opera omnia, ed. Borgnet, 33: 398b: tr. 18, q. 122.1.3: 'Et isti dicunt quod pollutio non sit peccatum nisi ex consensu qui post somnum impletur in vigilando, et secundum quantitatem illius consensus accipit quantitatem peccati. Dicunt etiam, quod talis pollutio initium habet in somnis, et complementum ex consensu in vigilando.'

${ }^{109}$ Bonaventure, In Sententiarum, in Opera omnia (Quaracchi: Ex typographia Collegii S. Bonaventurae, 1885), 2.632 (2.2): 'de cujus recordatione postmodum delectatur.'
} 
Animal est substantia states that the mortal sin could occur after the polluter 'returns to free will', thus making it clear that the pleasure is freely chosen. ${ }^{110}$

Albert's scenario creates an anomalous situation: a waking person commits a mortal sin by recalling and finding pleasure in the dream's fictional sexual encounter. The situation blurs both temporality and the distinction between the real and the imaginary: the memory is simultaneously of a fiction (the imagined sexual intercourse with an absent object of desire) and of the pleasure derived from the dream vision and from the actual emission in sleep. The images in the waker's mind may not have been 'true images', in the sense of true recollections of actual deeds, but such an observation is irrelevant in this context: the enjoyment of the memory - real or not - endangers the soul.

Once again, there is an interplay between past and present, although in this case, it is a reversal of the model we have previously encountered: it is now the sleeping state which affects the moral status of the individual in the waking state. In these thirteenth-century discussions, the role of recollection, both during sleep when the imagination recalls waking desires and here when the waking person recalls the sexual gratification of the dream, problematised the waking states at either end of sleep. The sleeping mind could bring moral condemnation both retrospectively and prospectively, as the imaginative power of the dream both satisfies earlier passions and brings pleasure afterwards.

\section{Conclusions}

Seminal emission in sleep was an object of particular interest in the twelfth and thirteenth centuries, as seen in the wide variety of materials which attempted to explain the phenomenon. Exactly why interest in nocturnal pollution was so considerable and widespread

\footnotetext{
${ }^{110}$ Summa Animal est substantia, 96; dist. 6): 'non sit mortale peccatum, nisi tamen homo post pollutionem rediens ad liberum arbitrium delectetur.'
} 
is not easy to identify. The twelfth-century theological emphasis on intentionality may have influenced the decision to devote so much attention to such a seemingly obscure topic. New modes of understanding the body and mind via the introduction of Galenic medicine from the later eleventh century onward may equally have played a role. Certainly the prominence of Pseudo-Gregory's letter in canon law, with the flood of commentaries on Gratian's

Decretum, as well as the letter's inclusion in thirteenth-century commentaries on Peter Lombard's Sentences, ensured that the issue would receive sustained discussion in the early scholastic world.

Despite the different genres in which the topic appeared, the essential framework for understanding nocturnal pollution remained relatively constant, with a shared understanding of how the mind, and specifically the imagination, worked in sleep. The imagination provided an explanatory model which could serve the different purposes of the literatures which invoked it. Natural-philosophical and medical materials addressed the relationship between waking sense perceptions and dream imagery, and theological, canon law and confessional literature participated in the same model. Most sources sought to explain how and why these emissions occurred, and focused on how the mind could influence the body during sleep. But the religious sources took the model one step further and invoked it in their attempts to work out the moral implications of nocturnal pollution. ${ }^{111}$ The nature of sleep complicated any simple attempt to explain the culpability of the polluter, and allowed for further exploration of the relationship between thought, action, sleep and sin. New questions allowed for an expanded discussion of the workings of the mind and their relation to the soul.

\footnotetext{
${ }^{111}$ It is worth noting that the only medieval treatise entirely devoted to the subject, Jean Gerson's fifteenthcentury De pollutione nocturna, discusses the mental aspects of nocturnal emissions far less often than the earlier sources discussed above. The text postdates the period under discussion here but has been discussed by Elliott, Fallen Bodies, 23-9.
} 
Nocturnal emissions stood at the crossroads of mind, body and soul, and complicated the relationship between waking and sleeping as well as free will and a lack of control. Yet paradoxically despite the discussion of the incapacities and weaknesses of the sleeping mind, the sources indicate that, during sleep, the imagination was powerful and able to influence the body enough to induce an involuntary seminal emission. The invocation of the imagination provided a framework which emphasised the influence of the prior waking state on the sleeper's mind and body. This return of daytime thoughts and desires in sleep finds a parallel in the further argument that recollections of sleeping fantasies could surface as the sleeper awakened. The three temporal categories - of waking, sleeping and re-awakening demonstrated the interconnected nature of the daily experiences. The sleeper might have been conceived as radically different from the waking person in some texts, but ultimately the power of the imagination prevented a full separation of the two persons.

The dangers of sleep in the central Middle Ages were in this instance concentrated on one of the inevitable consequences of sleep: the dreamer's inability to control either the images which appeared in his head or his emotional and physical response to those images. As such, each person could commit sinful acts entirely against his or her will. The best defence against succumbing to lewd images in sleep eventually became a form of preparation of the mind and soul before bed. This is not the place to discuss the many means by which medieval people strengthened body, mind and soul against the moral dangers of sleep, except to note that once again the mind was central to these preparations. Various prayers, readings, and rituals were used to soothe and purify the mind at bedtime. Yet, as noted in several sources, even after careful preparation a nocturnal emission could still occur, because the vestiges of earlier erotic thoughts remained in the sleeper's imagination. ${ }^{112}$

\footnotetext{
112 Glossa ordinaria on the Decretum, 21 (dist. 6). See also Albert, Commentarii in IV sententiarum, in Opera omnia, ed. Borgnet, 29: 234b (4.9b, sed contra 6).
} 
In their search for causes, medieval writers wrestled with crucial questions of human psychology, in particular the unique status of the mind in sleep. The resting mind presented distinct problems which reflected the otherness of sleep, as a state radically different from the waking state, a state which defied rationality and was thought occasionally to lay bear the emotional state of the waking self. The anomalous nature of nocturnal pollution, as a phenomenon inexplicable through normal cognitive and sensory processes, paralleled - and was explained by - the equally anomalous state of the sleeping mind. The sleeping mind may have functioned radically differently but it reflected and revealed the raw emotions of the waking mind. Freud's notion of dreams as the royal road to the unconscious does not directly apply here, since what the erotic dream articulates is not a hidden desire but one which the waking mind had knowingly contemplated. Nonetheless, some of the sources argue that nocturnal pollutions performed a role close to the Freudian idea of dreams as wish fulfilments, in this case fulfilment of a conscious desire for a specific individual. Ultimately natural philosophical, medical, theological and canon law writers all agreed that the simple, uncritical and irrational mind of the sleeper was able to recall the thoughts and desires of the waking state and give fantastical and physical expression to them. Such an understanding of the sleeping mind, expressed throughout the twelfth- and thirteenth-century sources, revealed concerns over the irrationality, base desires and lack of control exhibited in sleep, as a reflection of the weaknesses and limitations of what it meant to be human.

\section{Acknowledgements}

This study has greatly benefited from comments by Anthony Bale of Birkbeck, University of London, and Nancy Mandeville Caciola of the University of California, San Diego, who both read drafts of the article, and from the audience of seminar talks in History and Philosophy of 
Science at the University of Leeds, the Wellcome Unit for the History of Medicine at the University of Oxford, and Medieval and Renaissance Studies at University College London.

\section{Note on contributor}

William MacLehose is Lecturer in History and Philosophy of Science at UCL's department of Science and Technology Studies. He is a historian of medieval medicine and culture. He is the author of 'A Tender Age': Cultural Anxieties over the Child in the Twelfth and Thirteenth Centuries (New York: Columbia University Press, 2009) and is currently working on a study of sleep and its pathologies in medieval culture. 